\title{
The Atlantic Ocean at the Last Glacial Maximum: 2. Reconstructing the Current Systems with a Global Ocean Model
}

\author{
A. Paul ${ }^{*}$ and C. Schäfer-Neth \\ DFG Forschungszentrum Ozeanränder, Universität Bremen, Postfach 3304 40, \\ 28334 Bremen, Germany \\ *corresponding author(e-mail): apau@palmod.uni-bremen.de
}

\begin{abstract}
We use a global ocean general circulation model (OGCM) with low vertical diffusion and isopycnal mixing to simulate the circulation in the Atlantic Ocean at present-day and the Last Glacial Maximum (LGM). The OGCM includes $\delta^{18} \mathrm{O}$ as a passive tracer. Regarding the LGM sea-surface boundary conditions, the temperature is based on the GLAMAP reconstruction, the salinity is estimated from the available $\delta^{18} \mathrm{O}$ data, and the wind-stress is derived from the output of an atmospheric general circulation model. Our focus is on changes in the upper-ocean hydrology, the large-scale horizontal circulation and the $\delta^{18} \mathrm{O}$ distribution. In a series of LGM experiments with a step-wise increase of the sea-surface salinity anomaly in the Weddell Sea, the ventilated thermocline was colder than today by $2-3^{\circ} \mathrm{C}$ in the North Atlantic Ocean and, in the experiment with the largest anomaly ( 1.0 beyond the global anomaly), by $4-5^{\circ} \mathrm{C}$ in the South Atlantic Ocean; furthermore it was generally shallower. As the meridional density gradient grew, the Antarctic Circumpolar Current strengthened and its northern boundary approached Cape of Good Hope. At the same time the southward penetration of the Agulhas Current was reduced, and less thermocline-to-intermediate water slipped from the Indian Ocean along the southern rim of the African continent into the South Atlantic Ocean; the 'Agulhas leakage' was diminished by up to $60 \%$ with respect to its modern value, such that the cold water route became the dominant path for North Atlantic Deep Water (NADW) renewal. It can be speculated that the simulated intensification of the Benguela Current and the enhancement of NADW upwelling in the Southern Ocean might reduce the import of silicate into the Benguela System, which could possibly resolve the 'Walvis Opal Paradox'. Although $\delta^{18} \mathrm{O}_{\mathrm{w}}$ was restored to the same surface values and could only reflect changes in advection and diffusion, the resulting $\delta^{18} \mathrm{O}_{c}$ distribution came close to reconstructions based on fossil shells of benthic foraminifera.
\end{abstract}

\section{Introduction}

\section{Current Systems}

In the present-day eastern South Atlantic Ocean, the surface waters flow northward with the Benguela Current (Figure 1). They become warmer and, because of the high evaporation in the subtropics, saltier. A fraction crosses the equator and feeds the Gulf Stream and the North Atlantic Drift to eventually reach the subpolar North Atlantic Ocean. Here these waters release their heat to the atmosphere and cool. Because of their high salin- ity, they become dense enough to sink to great depth in the Labrador and Nordic Seas and thus form deep water.

There are actually two distinct branches of the Benguela Current: the Benguela Oceanic Current (BOC) and the Benguela Coastal Current (BCC). The BOC is part of the South Atlantic subtropical gyre and includes thermocline as well as intermediate waters. At the surface, it is replenished from two sources: There is a supply of Indian Ocean water which originates in the Agulhas Current and 


\section{Surface Circulation of the Atlantic Ocean}

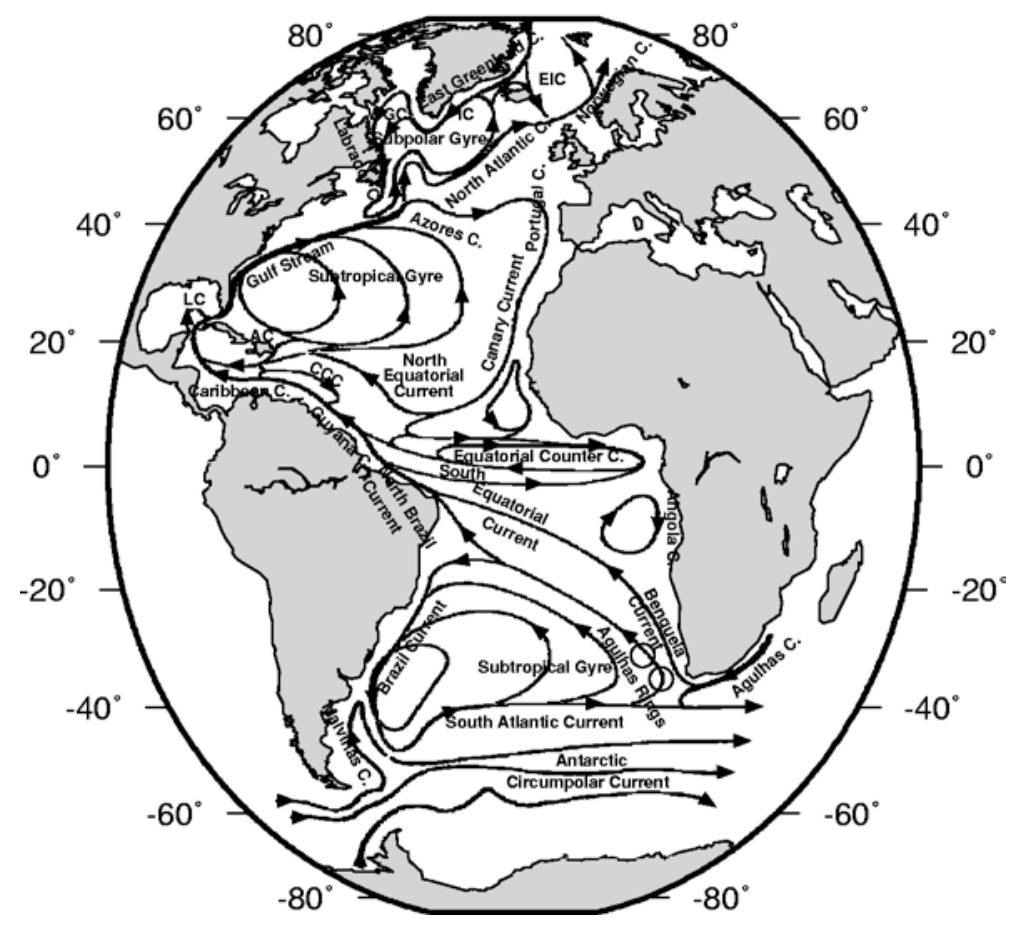

Fig. 1. Surface circulation of the Atlantic Ocean, based on Figure 14.2 of Tomczak und Godfrey (1994), which in turn is adapted from Duncan et al. (1982), Krauss (1986) and Peterson and Stramma (1991). Abbreviations are used for the East Iceland (EIC), Irminger (IC), West Greenland (WGC), Loop (LC) and Antilles (AC) Currents and the Caribbean Countercurrent (CCC). Two Agulhas rings are shown in the Benguela System off the coast of southwest Africa to indicate the role of eddy shedding in the Agulhas leakage.

slips into the South Atlantic Ocean around Cape of Good Hope. Because Indian Ocean water is relatively warm, this source is called the 'warm water route' (Gordon 1986). The remaining water is subantarctic surface water added at the Subtropical Front (STF, Shannon et al. 1989) or intermediate water that enters the South Atlantic Ocean through Drake Passage, upwells into the thermocline, warms up and flows eastward with the South Atlantic Current. This second source largely corresponds to the 'cold water route' first described by Rintoul (1991). Changes in the heat and salt transports from the South to the North Atlantic Ocean may be caused by changes in the relative contributions from these two routes and linked to the climate variations of the Quaternary (e.g. Berger and Wefer 1996; Boyle 2000). The upstream Agulhas Current may have undergone only limited glacial- interglacial change regarding its temperature, lateral position and latitude of retroflection (Winter and Martin 1990). However, there is evidence, e.g. from molluscs (Pether 1994), for warmer conditions in the Benguela System during the last deglaciation, as a result of enhanced advection close to the coast of water derived from the Agulhas Current and a concomitant suppression of upwelling.

The BCC flows on the south-west African shelf and transports upwelled cold water northwards. At about $15^{\circ} \mathrm{S}$ it meets the poleward Angola Current. The water that upwells along the coast in the distinct cells of the Benguela System is thermocline water from at most $400 \mathrm{~m}$ depth. It comprises Eastern South Atlantic Central Water (ESACW, which originates at the STF by mixing and sinking of subtropical and subantarctic surface water), South Indian central water (advected into the eastern 
South Atlantic Ocean in modified form by Agulhas rings and filaments) and tropical South Atlantic Central Water (SACW). The tropical Atlantic Ocean is a major source of thermocline water in the Benguela System. The northern Benguela System in particular is influenced by the Angola Current and the South Equatorial Current-Undercurrent system. Thermocline water and Antarctic Intermediate Water from the tropical Atlantic Ocean are advected polewards into the Benguela System certainly as far as $27^{\circ} \mathrm{S}$ (i.e. the Lüderitz cell). The oceanography of the southern Benguela System is more strongly affected by the Agulhas Current.

The relatively fresh, oxygen-rich ESACW is poor in nutrients and transported northward with the BOC. However, the saltier, oxygen-depleted SACW is greatly enriched in nutrients and transported poleward with a strong sub-surface flow (Shannon and Nelson 1996). Hence much of the nutrients used in the biological production off the coast of Namibia is brought in by poleward transport, from the high-concentration area north of Walvis Ridge. If this poleward transport were relatively decreased during glacial periods, by a weakening of the deep undercurrent as compared to the BOC, the quality of the upwelled water would be severely affected (Berger and Wefer 2002).

It has indeed been inferred from proxy data that the flow of the Benguela Current was slighty more intense at the Last Glacial Maximum (LGM), which led to a northward shift of the Angola-Benguela Frontal Zone by a few degrees (Jansen et al. 1996). Such a shift could be associated with a reduced import of nutrients (such as silicate) into the northern Benguela System and contribute to the paradoxical decrease of the production of diatoms and their flux to the sea floor during glacial periods ('Walvis Opal Paradox', Berger and Wefer 2002).

\section{Modeling the Paleo-Ocean}

This study was initiated by the sub-project C2 "Modeling the Paleo-Ocean" of the Special Research Project (Sonderforschungsbereich, SFB) 261, "The South Atlantic during the Late Quaternary: Reconstruction of mass budget and current systems", funded by the Deutsche Forschungsgemeinschaft (DFG). The goal of this effort was to reconstruct the LGM state of the South Atlantic Ocean. The focii were on the exchange between the South Atlantic and the other oceans:

- Changes in the exchange of water, heat and salt between the South Atlantic Ocean and the North Atlantic, Pacific and Indian Oceans, across the equator and through the circumpolar and Agulhas current systems

- Influence of the Antarctic Intermediate Water (AAIW) and Antarctic Bottom Water (AABW) on the North Atlantic Ocean

- Changes in the distribution of conservative tracers (temperature, salinity and $\delta^{18} \mathrm{O}_{\mathrm{w}}$ )

- Changes in biologic production and the distribution of biogeochemical tracers (e.g. $\delta^{13} \mathrm{C}$ )

The LGM and the modern states represent two extremes of the climate variability during the Late Quaternary. They are particularly useful test cases for climate models because they are best documented by (proxy-) data, which enables us to force and validate climate models.

In the SFB 261, we employed two coarse-resolution ocean general circulation models: the largescale geostrophic (LSG) ocean model, originally developed by the Max Planck Institute of Meteorology in Hamburg, Germany, and modified in the SFB 261, and the Modular Ocean Model (MOM), provided by the Geophysical Fluid Dynamics Laboratory (GFDL) in Princeton, USA. The modifications to the original LSG code included the implementation of a new tracer advection scheme (see Schäfer-Neth and Paul 2001 and Matthies et al. this volume for further details). Overall, the MOM turned out to be more flexible in testing different vertical resolutions and mixing parameterizations.

We used the LSG model to carry out a number of sensitivity experiments, which resulted in a robust circulation pattern for the glacial ocean. This provided the bases for a synthesis of a global and a regional study of the Atlantic Ocean at the LGM (Schäfer-Neth and Paul 2001) as well as for two simulations of the ocean carbon cycle (Matthies et al. this volume; Schulz and Paul 2003).

With the help of the MOM, we simulated the present-day distribution of the oxygen-isotopic con- 
tent of sea water, in good agreement with the GEOSECS data (Paul et al. 1999).

Here we present the first step towards a similar simulation with the MOM for the last glacial maximum. Furthermore, we discuss glacial-interglacial changes in the South Atlantic Ocean circulation at a regional scale, e.g. in the Brazil and Malvinas currents. In constructing the surface boundary conditions we used the proxy-data acquired by the SFBs 261 and 313 ("Veränderungen der Umwelt: Der nördliche Nordatlantik", ChristianAlbrechts-Universität zu Kiel) over a ten-year period. To compute meaningful $\delta^{18} \mathrm{O}_{\mathrm{w}}$ values and compare them with $\delta^{18} \mathrm{O}$ values of benthic foraminifera, we had to reduce the temperature error in the thermocline. To this end, we used relatively high vertical resolution, low vertical diffusion and state-of-the-art parameterizations of isopycnal mixing and eddy-induced tracer transport.

Our accompanying contribution (Schäfer-Neth and Paul this volume) deals with the details of the underlying sea-surface temperature (SST) reconstruction and assesses different gridding methods. In contrast to our previous study (Paul and SchäferNeth 2003), we now use as model forcing the SST fields obtained with the most reliable gridding technique (i.e. variogram analysis and kriging) applied to the proxy-data at the core locations, to simulate the glacial-to-interglacial changes in the hydrology and circulation of the Atlantic Ocean.

In our model, a fraction of the Agulhas Current leaked into the South Atlantic Ocean. Since the horizontal resolution was too coarse to resolve the eddies that are generated in the retroflection region and shed into the South Atlantic Ocean, only a broad westward advective transport was simulated (cf. England and Garçon 1994); in addition some westward diffusive transport of heat was invoked in terms of the isopycnal and eddy transport parameterizations. We find a reduced Indian-South Atlantic Ocean exchange at the LGM and a slightly intensified BOC that flowed in a more northerly direction along the coast off Namibia and Angola. We furthermore report on changes in thermocline ventilation, large-scale circulation and the $\delta^{18} \mathrm{O}_{w}$ and $\delta^{18} \mathrm{O}_{c}$ distribution implied by altered advection and diffusion.

\section{Methods}

\section{Data}

For a detailed description of the database used for forcing the model experiments, of the gridding process involved, and for a discussion of the errors within the data, the reader is referred to our accompanying publication (Schäfer-Neth and Paul this volume). In the following we give a short overview.

Sea Surface Temperature. We employed the SST estimates for the GLAMAP (Sarnthein et al. 2003) and EPILOG (Mix et al. 2001) chronozones that overlap in a common time span between 19000 and 22000 calendar years before present (BP). This data set was not only subject to a common stratigraphic control, but was also based on the same modern reference data set for the calibration of the transfer techniques, which greatly improved the data consistency despite different transfer or modern analog formulae. It includes more than 220 individual SST samples for boreal winter and more than 170 samples for boreal summer, which cover almost the entire Atlantic Ocean. We filled the remaining gaps by SST estimates from other publications, carefully selected to avoid discrepancies with the GLAMAP data. In addition to the SST reconstructions, new estimates for the extent of the glacial sea-ice cover were provided by the GLAMAP group. This information was included into the SST data base by setting SST to the freezing point over the respective regions. From the raw data, we produced regularly gridded $\left(1^{\circ} \times 1^{\circ}\right)$ summer and winter fields for the entire Atlantic Ocean by variogram analysis and kriging. We then smoothly incorporated these fields into the CLIMAP (1981) data set to produce improved new global SST maps. Following the PMIP (1993) approach, we constructed twelve monthly data sets by fitting a sinusoidal cycle to the winter and summer glacialto-modern anomalies and then adding the modern monthly SSTs (10 m values from the World Ocean Atlas WOA 1998). Finally, these monthly data sets were interpolated to the model grid.

Sea Surface Salinity. For the northern North Atlantic Ocean, we estimated the sea-surface salin- 
ity (SSS) at the LGM from the reconstructed SST and the oxygen isotopic composition of fossil foraminiferal shells $\delta^{18} \mathrm{O}_{c}$ using a method that has been developed over the last decade (Duplessy et al. 1991; Weinelt et al. 1996; Schäfer-Neth 1998; Schäfer-Neth and Paul 2001). In total, we employed $143 \delta^{18} \mathrm{O}_{\mathrm{c}}$ measurements from this region. The oxygen isotope ratio of sea water $\delta^{18} \mathrm{O}_{w}$ was computed according to the paleotemperature equation of Epstein et al. (1953) and the species-dependent SST corrections given in Weinelt et al. (1996). SSS was calculated from $\delta^{18} \mathrm{O}_{w}$ using a linear correlation between these properties. The parameters of this correlation were derived from the GISS $\delta^{18} \mathrm{O}$ Database (Schmidt et al. 1999; Bigg and Rohling 2000) and vary with latitude. For the remaining ocean, we used a global glacial-to-modern salinity shift of 1.07 (which, with respect to the whole depth of the ocean and not just its surface, corresponds to a change in relative mean sea level of about $100 \mathrm{~m}$ ). Following the evidence from the South Atlantic Ocean (Melles 1991; Duplessy et al. 1996), we applied an additional SSS anomaly of 0.55 and 1.0 in the Weddell Sea that went beyond the global shift (Experiments GB and GC in Table 1). The seasonal cycle of SSS was constructed by adding the difference between the gridded glacial reconstruction and the boreal Summer salinity taken from the $10 \mathrm{~m}$ (WOA 1998) analyses to the monthly modern salinity fields.

Oxygen Isotopic Composition of Surface Waters. In addition to $\mathrm{T}$ and $\mathrm{S}$, our model carried the oxygen isotopic composition of seawater as a third tracer. To force the $\delta^{18} \mathrm{O}_{\mathrm{w}}$ at the sea surface, we used the values for the upper $100 \mathrm{~m}$ from the GISS $\delta^{18} \mathrm{O}$ database (Bigg and Rohling 2000; Schmidt et al. 1999). The forcing was applied as a restoring boundary condition for all model grid cells for which $\delta^{18} \mathrm{O}_{\mathrm{w}}$ measurements were available from the database, as indicated by the colored circles in Fig-

\begin{tabular}{lll} 
Experiment & Time period & Additional Weddell Sea SSS anomaly \\
\hline M & modern & no \\
GA & LGM & no \\
GB & LGM & intermediate $(0.55)$ \\
GC & LGM & large $(1.0)$
\end{tabular}

Table 1. List of model experiments. ure 16. All other surface points of the model were allowed to evolve freely. The restoring values were computed as the annual mean of all $\delta^{18} \mathrm{O}_{w}$ data from the upper $100 \mathrm{~m}$ of the ocean that fell in the respective grid cell. We employed the modern $\delta^{18} \mathrm{O}_{\mathrm{w}}$ data for all runs. Thus, although we cannot present a true simulation of glacial $\delta^{18} \mathrm{O}_{w}$, changes in this passive tracer help to discriminate between hydrographic and circulation changes between the control and glacial model experiments.

Wind Stress. The wind stress anomaly for the glacial model experiments was derived from the control run of the European Centre/Hamburg atmospheric general circulation model (ECHAM3) at T42 resolution and a run that employed the GLAMAP SST fields as bottom boundary condition. (Lorenz and Lohmann, pers. comm.; these SST fields were gridded using a different interpolation technique, for a more detailed discussion, see Paul and Schäfer-Neth 2003). Differences to the SST maps used here are discussed in Schäfer-Neth and Paul (this volume). All glacial model runs presented here were driven by these wind fields to isolate the effect of the different thermohaline boundary conditions.

\section{Model}

We applied Version 2 of the Modular Ocean Model (MOM 2, Pacanowski 1996) to the global ocean. The resolution, geometry and bottom topography were similar to the coarse-resolution model of Large et al. (1997). The longitudinal resolution was constant at $3.6^{\circ}$, whereas the meridional resolution was $1.8^{\circ}$ near the equator, decreased to a minimum of $3.4^{\circ}$ away from the equator, then increased in midlatitudes as the cosine of latitude and was finally kept constant at $1.8^{\circ}$ poleward of $60^{\circ}$. There were 27 vertical levels with monotonically increasing thickness from $12 \mathrm{~m}$ near the surface to $450 \mathrm{~m}$ near the bottom. The minimum model depth was $49 \mathrm{~m}$, corresponding to 3 vertical levels, and the maximum model depth was $5900 \mathrm{~m}$.

The modern bottom topography of the model was obtained from the ETOPO5 topography data (NCAR Support Section 1986). To derive the glacial bottom topography, we computed the glacial anomaly from the Peltier (1994) reconstruction and 
added it to the modern bottom topography. Either topography was first interpolated to the model grid and then smoothed and adjusted according to the procedure outlined by Large et al. (1997).

We took the vertical diffusion coefficient to be depth-dependent (Bryan and Lewis 1979):

$$
A_{\mathrm{tv}}=A_{0}+\frac{C_{\mathrm{r}}}{\pi} \arctan \left[\lambda\left(z-z_{0}\right)\right]
$$

where we set $A_{0}=0.7 \times 10^{-4} \mathrm{~m}^{2} \mathrm{~s}^{-1}, C_{\mathrm{r}}=1.25 \times$ $10^{-4} \mathrm{~m}^{2} \mathrm{~s}^{-1}, \lambda=4.5 \times 10^{-4} \mathrm{~m}^{-1}$ and $z_{0}=2500 \mathrm{~m}$. Thus $A_{\mathrm{tv}}$ ranges from $0.1 \times 10^{-4} \mathrm{~m}^{2} \mathrm{~s}^{-1}$ near the surface to $1.3 \times 10^{-4} \mathrm{~m}^{2} \mathrm{~s}^{-1}$ near the bottom. Above the turnover depth $z_{0}$, the vertical diffusion coefficient was smaller than in the previous studies of Paul et al. (1999) and Schäfer-Neth and Paul (2001). According to the few available observational estimates, a low value of $0.1 \times 10^{-4} \mathrm{~m}^{2} \mathrm{~s}^{-1}$ indeed seems to be appropriate below the permanent pycnocline and away from topography (Ledwell et al. 1993).

As an improvement over the two previous studies, we employed isopycnal mixing and the mesoscale eddy tracer transport parameterization of Gent and McWilliams (1990). The isopycnal diffusion and thickness diffusion coefficients were chosen to be equal, $A_{\mathrm{I}}=A_{\mathrm{ITD}}=0.5 \times 10^{3} \mathrm{~m}^{2} \mathrm{~s}^{-1}$, and the horizontal diffusion coefficient $A_{\mathrm{hv}}$ was set to zero. The vertical and horizontal viscosity coefficients were $A_{\mathrm{mv}}=16.7 \times 10^{-4} \mathrm{~m}^{2} \mathrm{~s}^{-1}$ and $A_{\mathrm{mh}}=2.5 \times$ $10^{5} \mathrm{~m}^{2} \mathrm{~s}^{-1}$.

To relax the diffusive stability limit imposed on the model time step by the converging meridians at high latitudes, the horizontal mixing coefficients were tapered near the North Pole (Large et al. 1997). The isopycnal diffusion and thickness diffusion coefficients were reduced to $36 \%$ at $88.2^{\circ} \mathrm{N}$, and the horizontal viscosity coefficient was reduced to $53 \%$ and $20 \%$ at $85.5^{\circ} \mathrm{N}$ and $87.3^{\circ} \mathrm{N}$, respectively.

We used cross-land mixing to parameterize the exchange through the Bering Strait and the Strait of Gibraltar. Here the mixing coefficients were set such that the simulated inflow and outflow were equal to $0.8 \mathrm{~Sv}$ in the case of the Bering Strait and $1.75 \mathrm{~Sv}$ in the case of the Strait of Gibraltar. For the LGM experiments, the exchange through the Bering Strait was set to zero.
For the momentum and barotropic integrations, the time step was $1800 \mathrm{~s}$. The tracer time step was $2.5 \mathrm{~d}$ at all levels. All experiments were integrated for at least 2000 tracer years (Experiment $M$ for 5000 tracer years). Fourier filtering was applied to the flow variables south of $71.1^{\circ} \mathrm{S}$ and north of $71.1^{\circ} \mathrm{N}$, and to the tracer variables south of $70.2^{\circ} \mathrm{S}$ and north of $70.2^{\circ} \mathrm{N}$.

The surface momentum flux was provided by the zonal and meridional wind stress components, and the net surface heat and freshwater fluxes were computed by restoring the potential temperature and salinity at the first model level to prescribed monthly SST and SSS with a relaxation time scale of 50 days relative to the upper $50 \mathrm{~m}$. Seawater oxygen-18 $\left(\delta^{18} \mathrm{O}_{\mathrm{w}}\right)$ at the first model level was restored to the sparse modern annual-mean observations with the same relaxation time scale.

\section{Experimental Setup}

We carried out four model experiments (Table 1), one for the modern and three for the LGM time period:

- Experiment M was subject to modern sea surface boundary conditions. The sea-surface temperature and salinity fields were taken from the WOA 1998 data for $10 \mathrm{~m}$ depth. The wind stress fields were derived from the NCEP reanalysis data covering the four years 1985 through 1988 (Kalnay et al. 1996) as described by Large et al. (1997).

- Experiment GA employed the LGM SST reconstruction, SSS field and wind stress anomaly, all as described above.

- Experiment GB was run under the same conditions as Experiment GA, but with the 0.55 salinity anomaly in the Weddell Sea.

- Experiment GC employed the 1.0 salinity anomaly in the Weddell Sea.

The main difference between the LGM experiments discussed here and those presented in Paul and Schäfer-Neth (2003) is the use of the corebased as opposed to the isoline-based temperature reconstruction (see our accompanying publication Schäfer-Neth and Paul this volume). With respect to $\delta^{18} \mathrm{O}_{\mathrm{w}}$, Experiments GA-GC are not true simulations of the LGM, but important sensitivity experi- 
ments that isolate the effect of only the circulation changes on the distribution at depth, without changes of the surface hydrology. Our results for $\delta^{18} \mathrm{O}_{\mathrm{w}}$ and $\delta^{18} \mathrm{O}_{\mathrm{c}}$ are shown here for the first time.

\section{Diagnostics}

In diagnosing the model output, we used three different criteria of mixed-layer depth. The most common definition employs a constant density increment (here $0.125 \mathrm{~kg} \mathrm{~m}^{-3}$; Levitus 1982) and sets the minimum value to the depth of first model layer. Plots based on this definition can be compared to other work on the subduction process (e.g. Huang and Qiu 1994; Williams et al. 1995).

To further investigate the ventilation of the thermocline, we computed the thickness of the surface isothermal layer from the model output by extracting the depth where the temperature differed from the temperature at the surface by more than $0.5^{\circ} \mathrm{C}$; this depth is representative of the depth of the seasonal thermocline (Sprintall and Tomczak 1992; Tomczak and Godfrey 1994). In this connection, the thickness of the surface isopycnal layer is defined by the depth where the density is larger than the density at the surface by an amount which corresponds to the temperature change of $0.5^{\circ} \mathrm{C}$ used in the construction of the surface isothermal layer. To find these two thicknesses, we interpolated the local temperature and density linearly between the model depths. We took the annual maximum of the surface isothermal layer thickness as the lower boundary of the seasonal thermocline.

The depth difference between the surface isothermal and isopycnal layer can be different from zero. Positive differences show the presence of a barrier layer between the halocline and the thermo- cline that does not allow a heat flux through the bottom of the mixed layer. Negative differences in the subtropics are produced by the subduction process (Tomczak and Godfrey 1994). They are therefore a reliable indicator for the ventilation of the thermocline.

From the distribution of the mixed-layer density and the thickness of the barrier layer, we derived the density criteria for the base of the ventilated thermocline: We overlaid the density and thickness contours and picked the highest density values that fell in regions of negative barrier layer thickness near the poleward boundaries of the subtropical gyres. To define water mass boundaries between intermediate and deep water, and deep and bottom water, we identified the isopycnal surfaces that approximate the lower boundary of the salinity minimum in the South Atlantic Ocean and run through the center of the bottom water cell in the meridional overturning streamfunction for the Atlantic Ocean, respectively.

Calcite $\delta^{18} \mathrm{O}$ in equilibrium with ambient seawater was computed from the paleotemperature equation by Mulitza et al. (this volume).

\section{Results}

\section{Hydrology}

Our four model experiments yielded the global mean temperatures and salinities given in Table 2. As compared to Experiment M, the LGM sea-surface boundary conditions prompted a vertically averaged global mean cooling that ranged from $1.04^{\circ} \mathrm{C}$ in Experiment GA to $1.87^{\circ} \mathrm{C}$ in Experiment GC. At the same time, the ocean became saltier by 1.35 to 1.46 . At the sea surface, the cooling was $1.36^{\circ} \mathrm{C}$

\begin{tabular}{lcccccccc}
\hline Experiment & \multicolumn{2}{c}{ T } & \multicolumn{2}{c}{ SST } & \multicolumn{2}{c}{ S } & \multicolumn{2}{c}{ SSS } \\
& Atlantic & global & Atlantic & global & Atlantic & global & Atlantic & global \\
\hline M & 4.16 & 3.73 & 16.77 & 18.14 & 34.86 & 34.65 & 35.32 & 34.70 \\
GA & 3.71 & 2.69 & 14.07 & 16.78 & 34.30 & 36.01 & 36.48 & 35.87 \\
GB & 3.11 & 2.32 & 14.05 & 16.78 & 34.27 & 36.00 & 36.50 & 35.88 \\
GC & 2.48 & 1.86 & 14.04 & 16.78 & 34.35 & 36.11 & 36.52 & 35.88 \\
\hline
\end{tabular}

Table 2. Global mean temperatures and salinities, vertically integrated (T, S) and at the sea surface (SST, SSS). 
for the global ocean and $2.70-2.73^{\circ} \mathrm{C}$ for the Atlantic Ocean.

The changes in the surface hydrology were strongly influenced by the changes in the precribed wind stress distribution (Figure $2 \mathrm{a}$ and $\mathrm{b}$ ). The main characteristics of the glacial anomaly were the more prominent trades in the North Atlantic Ocean and the much stronger westerlies in the Southern Ocean. Consequently, the Ekman downwelling (computed from the divergence of the Ekman transport) increased in the subtropics of both hemispheres (Figure $2 \mathrm{c}$ and $\mathrm{d}$ ). There was only little change in the Ekman upwelling off the coasts of northwest and southwest Africa because there was hardly any change in the South Atlantic trades. The zero line clearly shows a southward shift of the westerlies in the Southern Ocean.

The winter mixed-layer depth in Experiment $\mathrm{M}$ (the mixed-layer depth during March in the northern hemisphere and September in the southern hemisphere, Figure 3) indicates that central water was formed near $40^{\circ}$ latitude in the subtropics of both hemispheres, and AAIW between $55^{\circ}$ and $60^{\circ} \mathrm{S}$ in the South Pacific Ocean, consistent with the distribution of Ekman downwelling. In addition, there was a general poleward deepening.

In all glacial experiments, the low surface salinities reconstructed from low surface $\delta^{18} \mathrm{O}_{w}$ values suppressed convection in the northern subpolar region, except for a small cell in the Irminger Sea where still some deep water was formed. A region of convection deeper than $200 \mathrm{~m}$ appeared at about $40^{\circ} \mathrm{W}$ in the northern subtropics. In the southern hemisphere, the band of mixed-layer depths larger than $100 \mathrm{~m}$ near $60^{\circ} \mathrm{S}$ extended from the South Pacific Ocean into the South Atlantic Ocean. In Experiment GC, the deep convection in the Weddell Sea clearly reflected the 1.0 SSS anomaly.

In Experiment M, the winter mixed-layer density (the potential density during March in the northern hemisphere and September in the southern hemisphere, referenced to the surface and averaged over the mixed-layer depth, Figure 4) was basically symmetric about the equator. It had low values in the tropics, became denser with latitude due to the increasing surface buoyancy loss and reached values higher than $27 \mathrm{~kg} \mathrm{~m}^{-3}$ in the sub- polar oceans of either hemisphere. The contrast between Experiment $\mathrm{GC}$ and Experiment $\mathrm{M}$ ranged from typically $2 \mathrm{~kg} \mathrm{~m}^{-3}$ units in the low latitudes to $1 \mathrm{~kg} \mathrm{~m}^{-3}$ unit in the high latitudes and was enhanced in the Weddell Sea due the additional salinity anomaly. Experiments GA and GB (not shown) differed from Experiment GC only in the magnitude of the enhanced density contrast in the Weddell Sea.

The additional salinity anomaly in the Weddell Sea was thought to reflect a larger sea-ice formation and export at the LGM. As demonstrated by Toggweiler and Samuels (1995b), the net rate of sea-ice formation and melting can be inferred from the restoring boundary condition on salinity. For the inner Weddell Sea in Experiment M, the implied net freezing rate was $0.061 \mathrm{~m} \mathrm{a}^{-1}$, and the corresponding divergence of the net surface freshwater flux was $4.87 \mathrm{mSv}$ (Table 3). These values changed sign in Experiments GA and GB. In Experiment GC, the fluxes were of the same sign as in Experiment M, but considerably larger.

Negative values of barrier layer thickness (Figure 5) occur where the depth of the isopycnal mixed layer exceeds the depth of the isothermal mixed layer and faithfully indicate the subduction of thermocline water (Sprintall and Tomczak 1992; Tomczak and Godfrey 1994).

In the subtropics, we identified the northeastern corner of the North Atlantic Ocean and the southwestern corner of the South Atlantic Ocean as those regions where the highest densities of the mixed layer coincided with the most negative values of barrier layer thickness. These regions determined the lower boundary of the ventilated thermocline. Mixed-layer densities in these regions were about $\sigma_{0}=26.9 \mathrm{~kg} \mathrm{~m}^{-3}$ in Experiment $\mathrm{M}$ and $\sigma_{0}=28.1 \mathrm{~kg} \mathrm{~m}^{-3}$ in Experiment GC (cf. Figure 3) and were used to trace the depth of the ventilated thermocline equatorward from its origin at the subtropical fronts. The alternating pattern of negative (or near-zero) and positive values of the barrierlayer thickness in the tropical Atlantic Ocean in Experiment M corresponds well to the present-day observations (Sprintall and Tomczak 1992).

The depth of the ventilated thermocline that followed from our density criteria is shown in Figure 6. In Experiment M, it was shallow near the 


\section{Sea Surface Wind Stress and Ekman Pumping}

\section{Modern \\ Wind Stress \\ Glacial Anomaly}
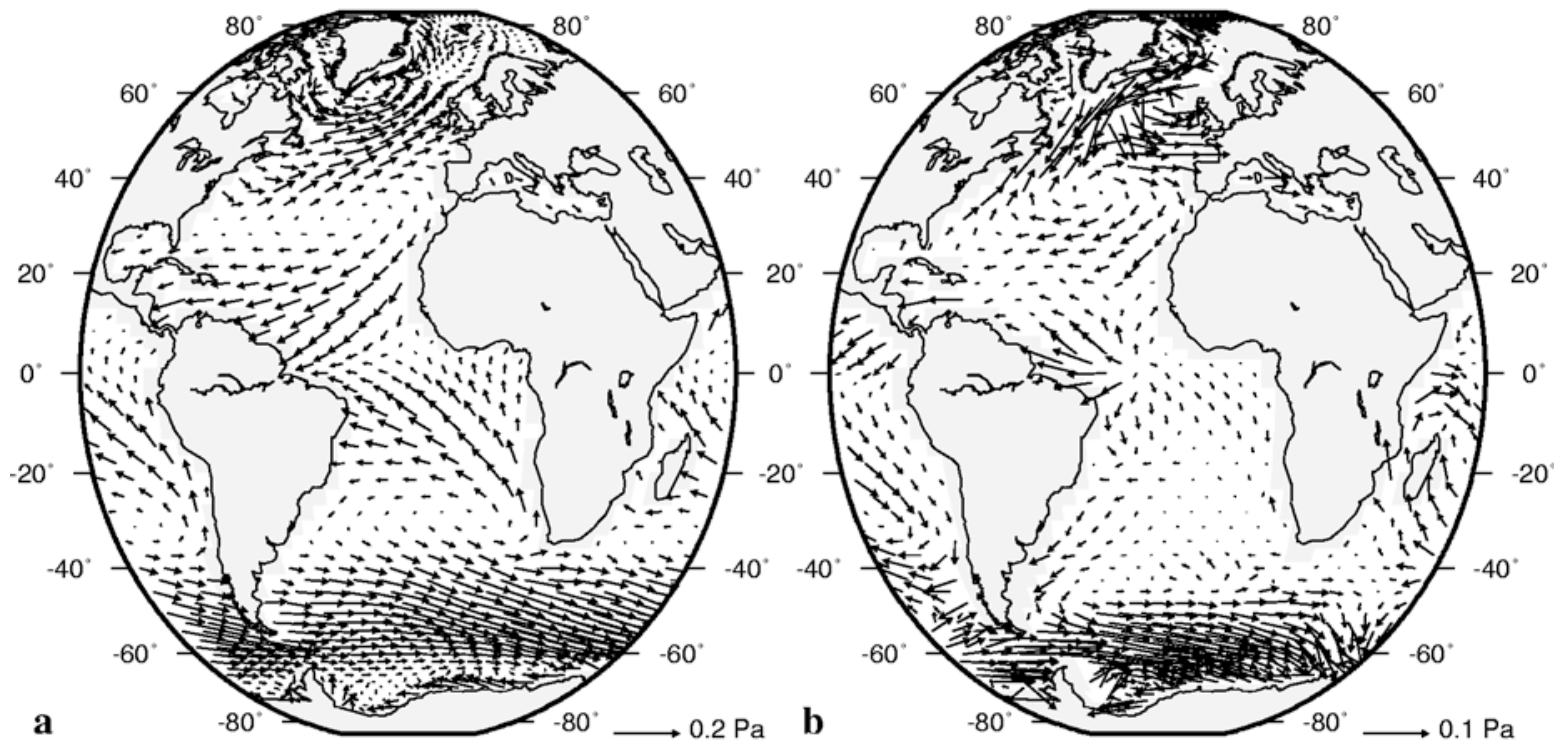

Modern

Ekman Pumping Velocity

Glacial Anomaly
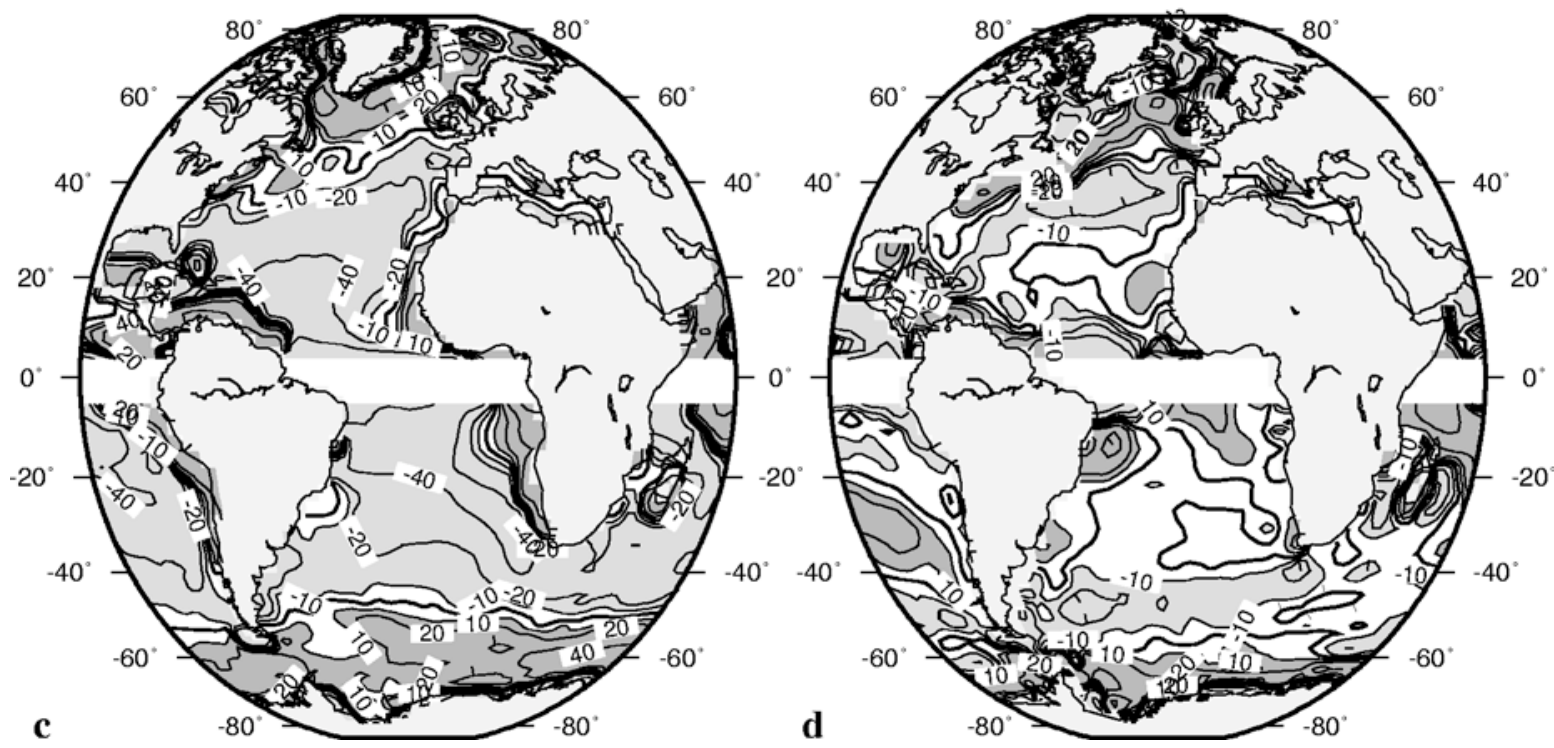

Fig. 2. Annual-mean wind stress and Ekman pumping. a) Modern wind stress distribution (Pa), derived from NCEP reanalysis data (Kalnay et al. 1996) and used in Experiment M. b) LGM wind stress anomaly (Pa), derived from the ECHAM3 atmospheric general circulation model and used in Experiments GA to GC. Note that the scale is doubled as compared to a. c) Modern Ekman pumping velocity, computed from the divergence of the Ekman transport $\left(\mathrm{m} \mathrm{a}^{-1}\right.$, Experiment $\left.\mathrm{M}\right)$. No values are plotted in the region between $5^{\circ} \mathrm{S}$ and $5^{\circ} \mathrm{N}$ where the Coriolis parameter tends to zero at the equator and it is impossible to compute a pumping rate. The thick contour denotes the zero line. Dark shading indicates positive, light shading negative values. d) LGM Ekman pumping velocity anomaly ( $\mathrm{m} \mathrm{a}^{-1}$, Experiments GA to GC). Annotation as in c. 


\section{Winter Mixed-Layer Depth}

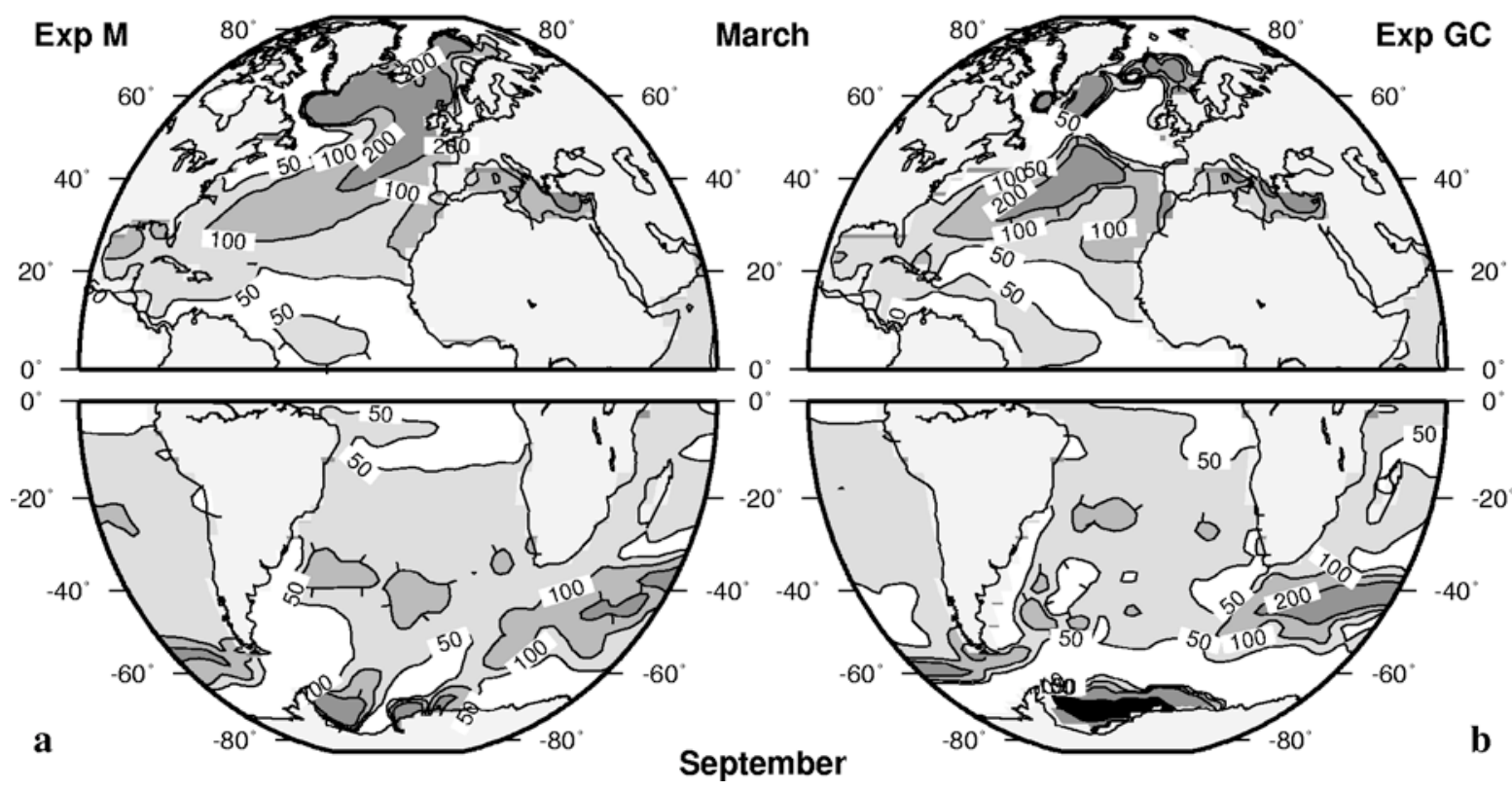

Fig. 3. Winter mixed-layer depth (m) for the Atlantic Ocean (March in northern hemisphere, September in southern hemisphere). a) Modern (Experiment M). b) LGM (Experiment GC). The mixed-layer depth is based on a constant density contrast $\left(\Delta \sigma_{0}=0.0125 \mathrm{~kg} \mathrm{~m}^{-3}\right)$. The contour interval is $50 \mathrm{~m}$. Values larger than $300 \mathrm{~m}$ are colored black.

\section{Winter Mixed-Layer Density}

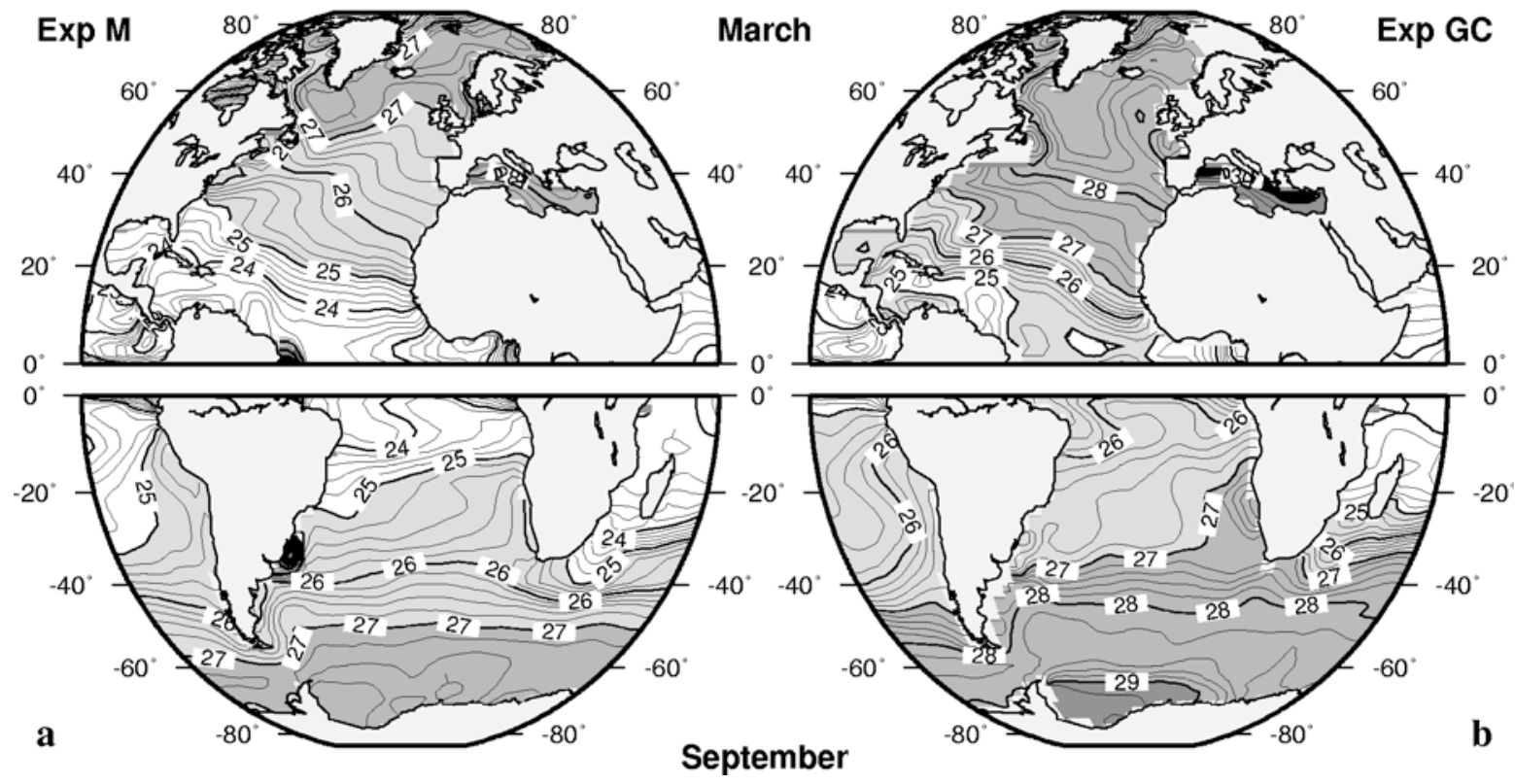

Fig. 4. Winter mixed-layer density $\left(\mathrm{kg} \mathrm{m}^{-3}\right)$ for the Atlantic Ocean (March in the northern hemisphere, September in the southern hemisphere). a) Modern (Experiment M). b) LGM (Experiment GC). The contour interval is $0.2 \mathrm{~kg} \mathrm{~m}^{-3}$. 


\section{Winter Barrier-Layer Thickness}

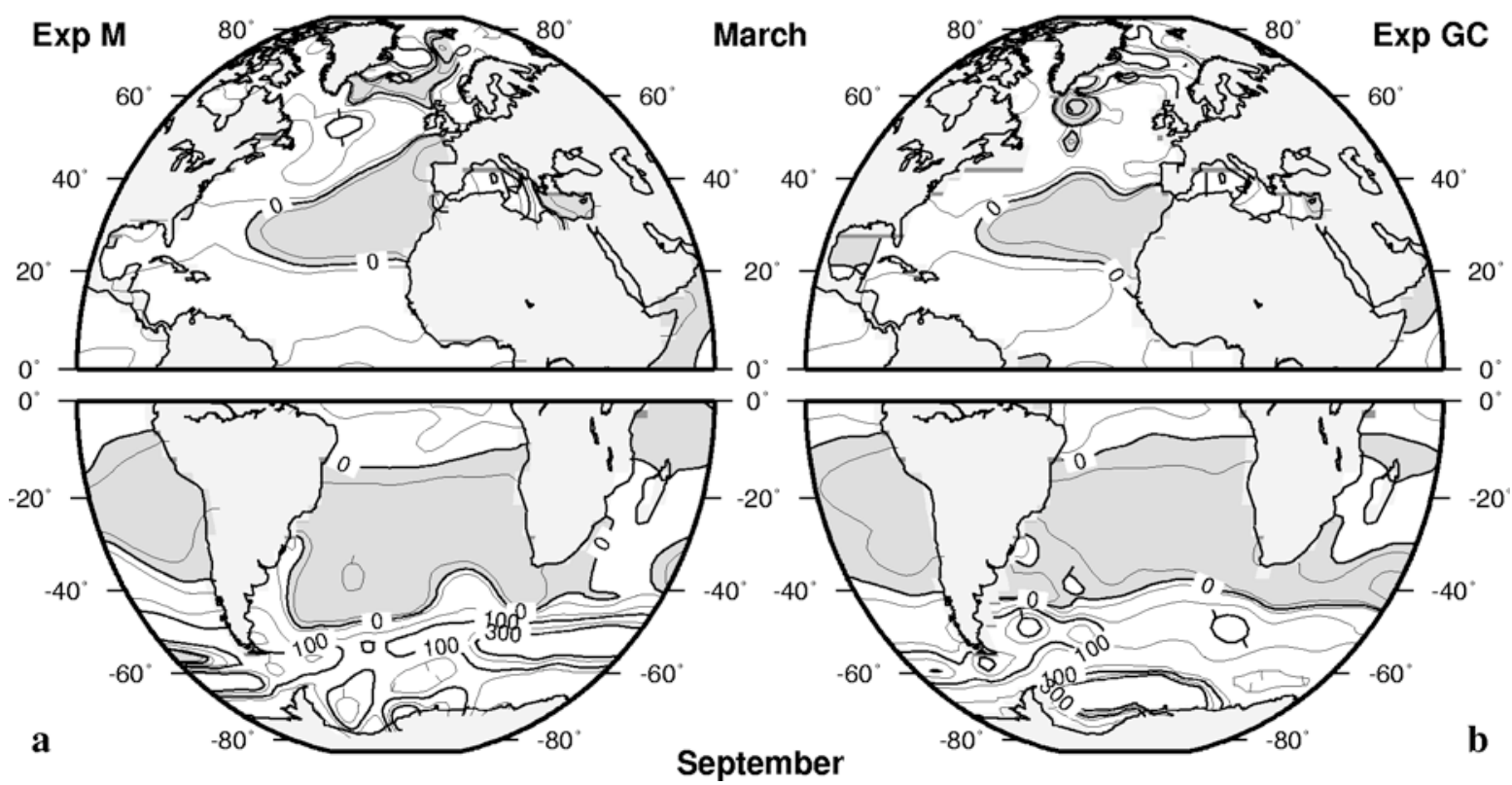

Fig. 5. Barrier layer thickness (depth difference between the isothermal and isopycnal mixed layer, $m$ ) for the Atlantic Ocean during winter (March in northern hemisphere, September in southern hemisphere). a) Modern (Experiment M). b) LGM (Experiment GC). Light shading indicates negative differences. Isolines are drawn at $0, \pm 5, \pm 10$, $\pm 50, \pm 100, \pm 200$ and $\pm 300 \mathrm{~m}$.

\section{Ventilated Thermocline Depth}

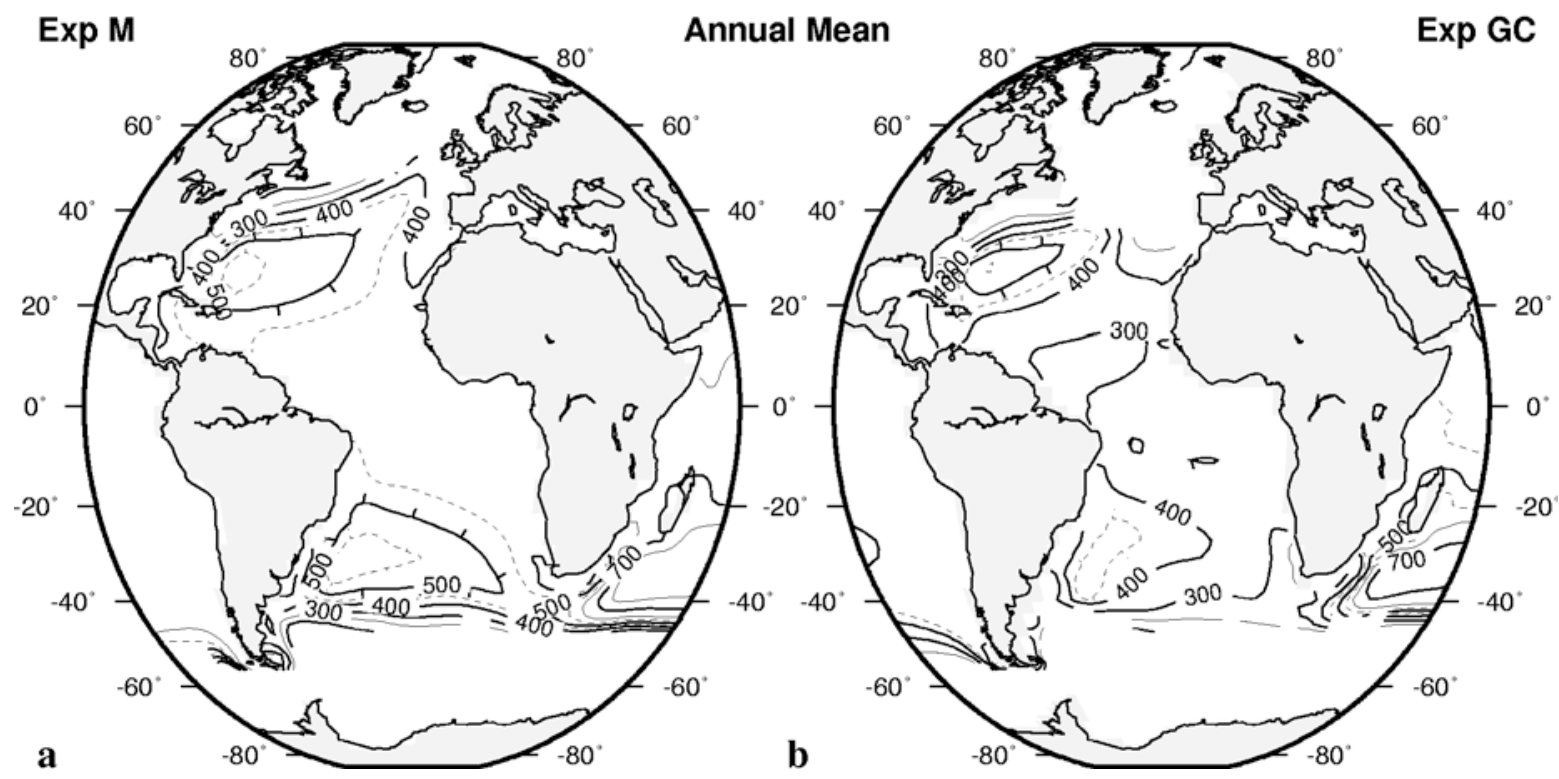

Fig. 6. Annual-mean maximum depth of the ventilated thermocline $(m)$ for the Atlantic Ocean. a) Modern (Experiment M, $\sigma_{0}=26.9 \mathrm{~kg} \mathrm{~m}^{-3}$ isopycnal surface). b) LGM (Experiment GC, $\sigma_{0}=28.1 \mathrm{~kg} \mathrm{~m}^{-3}$ isopycnal surface). The contour interval is $100 \mathrm{~m}$, additional contours are drawn at 450 and $550 \mathrm{~m}$ depth (dashed lines). 
Characteristic

Water flux $\left(\mathrm{m} \mathrm{a}^{-1}\right)$

Water divergence $(\mathrm{mSv})$

SSS

Table 3. Implied water flux, its divergence and the seasurface salinity (SSS) in the inner Weddell Sea (south of $63.9^{\circ} \mathrm{S}$ ). The implied water flux approximates the net sea-ice formation or freezing rate in the ocean model.

equator (400-450 $\mathrm{m}$ ) and near the outcrop regions, but reached up to $650 \mathrm{~m}$ in the centers of the subtropical gyres. During the LGM (as shown for Experiment GC), the tropical thermocline between $20^{\circ} \mathrm{S}$ and $20^{\circ} \mathrm{N}$ was up to $150 \mathrm{~m}$ shallower. At the same time the outcrop regions shifted equatorward in both hemispheres. As a result, the ventilated thermocline was shallower and reached only $500 \mathrm{~m}$ depth in the North Atlantic Ocean and 450 $m$ depth in the South Atlantic Ocean. In addition, the contour lines that follow the path of South Atlantic Current (cf. Figure 1) indicate the enhanced advection of colder and denser waters from the western South Atlantic Ocean into the Benguela
System that replaced the inflow of warmer waters from the Indian Ocean.

While the base of the ventilated thermocline shallowed in the equatorial region $\left(5^{\circ} \mathrm{S}-5^{\circ} \mathrm{N}\right)$, in the west more so than in the east (Figure 6), the mixedlayer and the permanent thermocline deepened in the west, at least during northern hemisphere summer (Figure 7). Thus we find a larger east-west slope of the mixed-layer depth as well as of the permanent thermocline, in agreement with the study by Wolff et al. (1999). However, it is also evident that this deepening went along with a general cooling by about $2{ }^{\circ} \mathrm{C}$. While the deepening was due to a strengthening of the trade winds, the cooling resulted from lower glacial SST and changes in ventilation at extra-tropical latitudes.

\section{Circulation}

Figure 8 shows the large-scale, depth-integrated horizontal circulation. The major meridional and horizontal volume transports are given in Table 4. In the southern hemisphere, the volume transport of the Antarctic Circumpolar Current (ACC) was $121 \mathrm{~Sv}$ in Experiment $\mathrm{M}$ and increased from 123

\section{Mixed-Layer Depth and Potential Temperature, Equatorial Atlantic, $5^{\circ} \mathrm{S}-5^{\circ} \mathrm{N}$ Experiment $\mathrm{M}$ \\ Experiment GC}

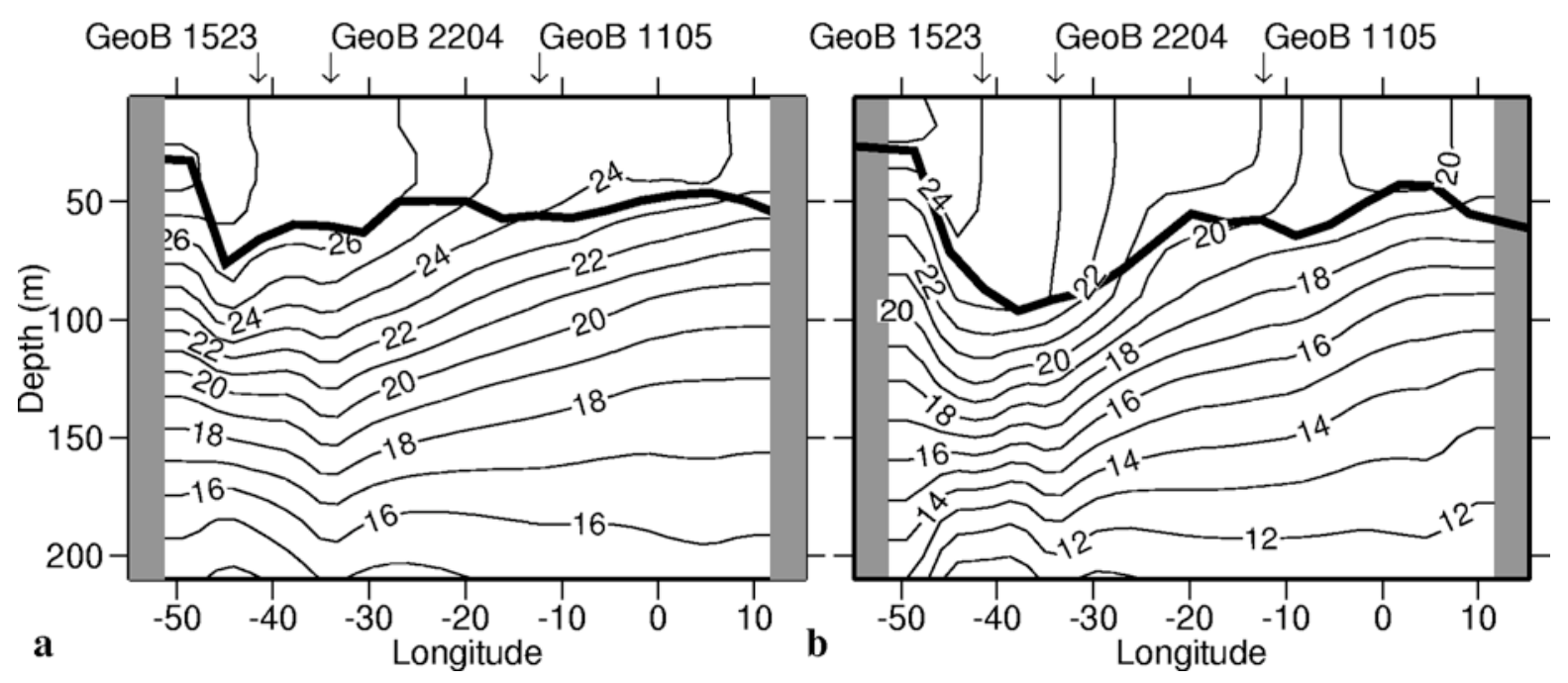

Fig. 7. Potential temperature $\left({ }^{\circ} \mathrm{C}\right)$ distribution in the equatorial Atlantic Ocean $\left(5^{\circ} \mathrm{S}-5^{\circ} \mathrm{N}\right)$ during September. The thick black line indicates the isothermal mixed-layer thickness. Arrows indicate the locations of the sediment cores studied by Wolff et al. (2000). 


\section{Horizontal Transport Streamfunction}
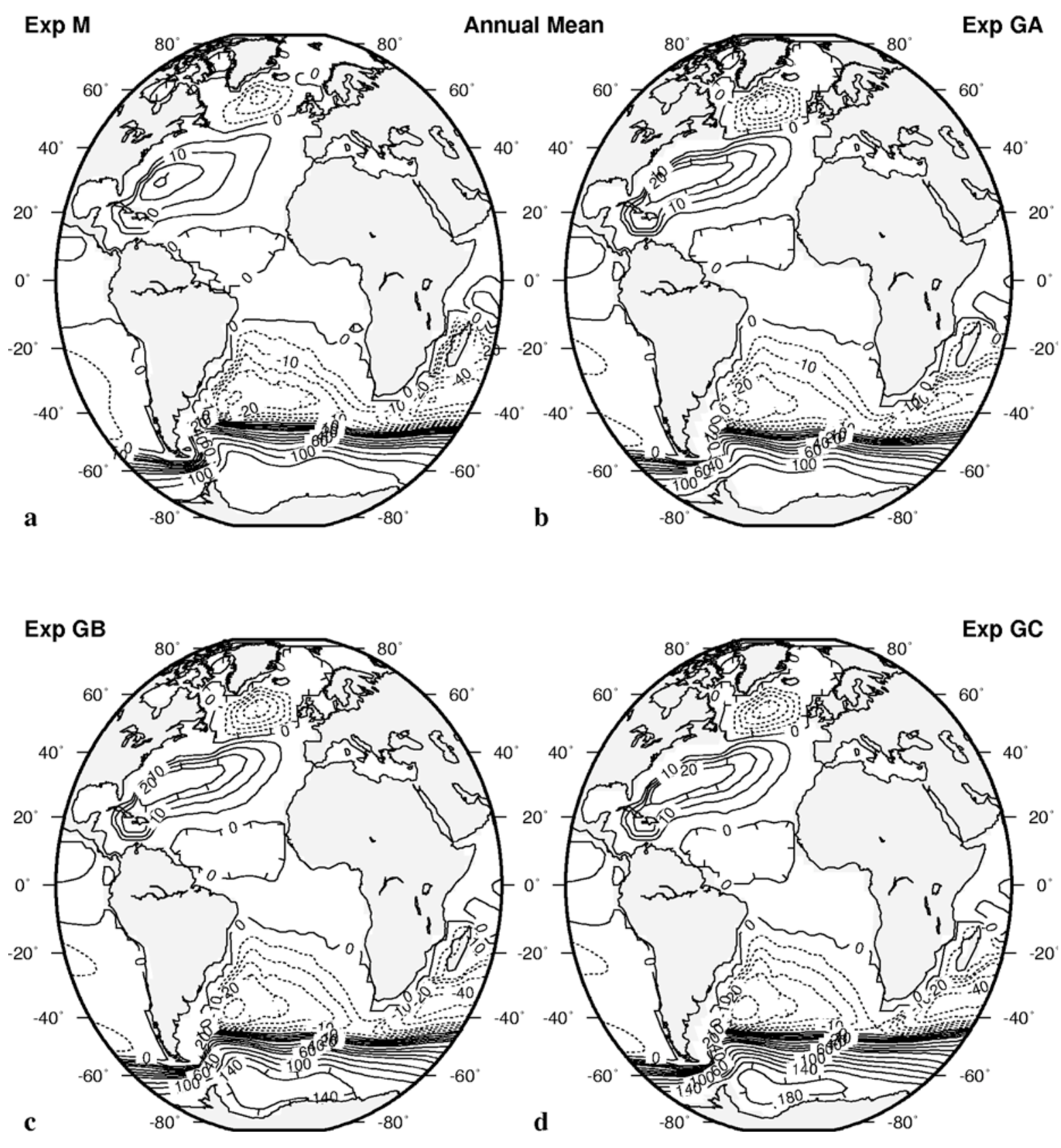

$\operatorname{Exp} \mathrm{GC}$

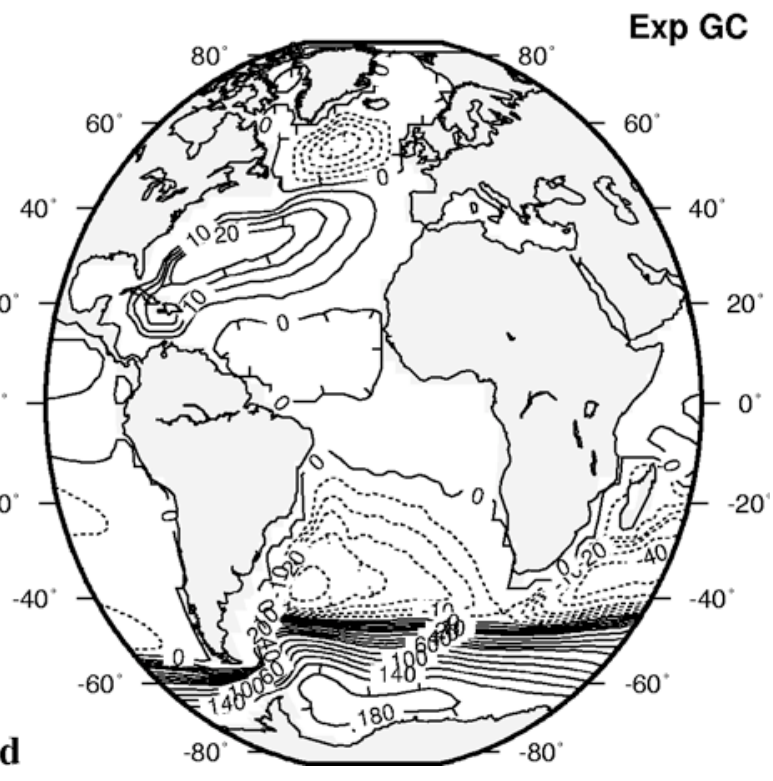

Fig. 8. Annual-mean vertically integrated volume transport (Sv) for the Atlantic Ocean as given by the barotropic streamfunction. The contour interval is $5 \mathrm{~Sv}$ up to $20 \mathrm{~Sv}, 10 \mathrm{~Sv}$ between $20 \mathrm{~Sv}$ and $80 \mathrm{~Sv}$, and $20 \mathrm{~Sv}$ for more than $80 \mathrm{~Sv}$. Dotted lines represent negative contour levels and indicate anti-clockwise circulation. a) Modern (Experiment M). b) LGM (Experiment GC). 


\begin{tabular}{lrrrr} 
Water mass, current & M & GA & GB & GC \\
\hline NADW (production) & 10 & 10 & 10 & 9 \\
NADW (outflow at $30^{\circ} \mathrm{S}$ ) & 8 & 10 & 9 & 9 \\
AABW (inflow at $30^{\circ} \mathrm{S}$ ) & 4 & 2 & 3 & 3 \\
\hline Northern subpolar gyre & 16.9 & 24.1 & 23.6 & 23.4 \\
Gulf Stream & 21.4 & 27.4 & 28.0 & 28.1 \\
Brazil Current & 32.6 & 32.3 & 34.0 & 36.4 \\
Agulhas Current & 62.3 & 46.5 & 48.0 & 49.0 \\
Agulhas leakage & 11.7 & 12.1 & 8.1 & 5.1 \\
ACC & 120.7 & 123.1 & 138.0 & 175.1 \\
Weddell Sea gyre & 19.1 & 12.3 & 14.4 & 13.5
\end{tabular}

Table 4. Major meridional and horizontal transports (Sv) simulated in the ocean model.

Sv in Experiment GA to $175 \mathrm{~Sv}$ in Experiment GC. At the same time, the Agulhas leakage was 11.7 $\mathrm{Sv}$ in Experiment $\mathrm{M}$ and decreased from 12.1 Sv in Experiment GA to 5.1 Sv in Experiment GC. In all LGM experiments, the Agulhas Current was weaker by about $25 \%$ than at present, while the volume transport of the Brazil Current (and correspondingly the Benguela Current) was roughly $10 \%$ larger. The confluence of the Brazil and Malvinas Currents shifted southward by one gridpoint. The Weddell Sea Gyre turned out to be weaker under LGM conditions. In the northern hemisphere, the volume transport of the Gulf Stream increased by roughly $30 \%$, and the North Atlantic Drift turned from a northwestward to a westward direction. The northern subpolar gyre intensified by nearly $40 \%$ and expanded southward.

The decreasing leakage of Indian Ocean waters from the Agulhas Current into the Atlantic Ocean was clearly reflected by changes in the horizontal transport and temperature over the depth range of the ventilated thermocline in the vicinity of Cape of Good Hope, as can be seen from Figure 9. This figure details the large-scale horizontal circulation and temperature in five layers: the seasonal thermocline, ventilated thermocline, intermediate water, deep water and bottom water (see Table 5 for the definition of the water mass boundaries). The flow in the seasonal thermocline (whose lower boundary is defined as the annual maximum of mixed-layer depth, Huang and Qiu 1994) again shows the more zonal path of the Gulf Stream and North Atlantic Drift in Experiment GC. The water recirculating with the northern subtropical gyre was eventually entrained into the thermocline, in which the southwest transport gradually increased. The thermocline water cooled by $2-3^{\circ} \mathrm{C}$ in the North Atlantic Ocean and $4-5^{\circ} \mathrm{C}$ in the South Atlantic Ocean. While the cooling in the North Atlantic Ocean was due to lower temperatures at the sea surface and enhanced ventilation, in the South Atlantic Ocean, less warm water was imported from the Indian Ocean and more and colder water was subducted at the Subtropical Front. A large cooling was also evident in the intermediate and deep water. In the North Atlantic Ocean, both were ventilated from further south in Experiment GC as compared to Experiment M. The transport of Antarctic Intermediate Water in the southern subtropical gyre and across the equator was slightly weaker. The northward flow of Antarctic Bottom Water was stronger, mainly in the western trough of the Atlantic Ocean, and reached further north; its potential temperature fell below $0^{\circ} \mathrm{C}$ everywhere.

There was actually no upwelling of intermediate water into the ventilated thermocline in the tropics (between $20^{\circ} \mathrm{S}$ and $20^{\circ} \mathrm{N}$ ), except for the Caribbean; there was very limited upwelling of deep

\begin{tabular}{lll}
\hline & Modern (Experiment M) & LGM (Experiment GC) \\
\hline Seasonal thermocline & Annual maximum of isothermal & Annual maximum of isothermal \\
mixed-layer depth & mixed-layer depth \\
Ventilated thermocline & $\sigma_{0}<26.9$ & $\sigma_{0}<28.1$ \\
Intermediate Water & $26.9<\sigma_{0}<27.5$ & $28.1<\sigma_{0}<28.8$ \\
Deep Water & $\sigma_{0}>27.5$ and $\sigma_{4}<45.9$ & $\sigma_{0}>28.8$ and $\sigma_{4}<47.45$ \\
Bottom Water & $\sigma_{4}>45.9$ & $\sigma_{4}>47.45$ \\
\hline
\end{tabular}

Table 5. Definition of water mass boundaries. Potential densities $\left(\sigma_{0}=\right.$ referenced to the surface, $\sigma_{4}=$ referenced to $4000 \mathrm{~m}$ depth) are given in $\mathrm{kg} \mathrm{m}^{-3}$. 


\section{Horizontal Volume Transport and Temperature}
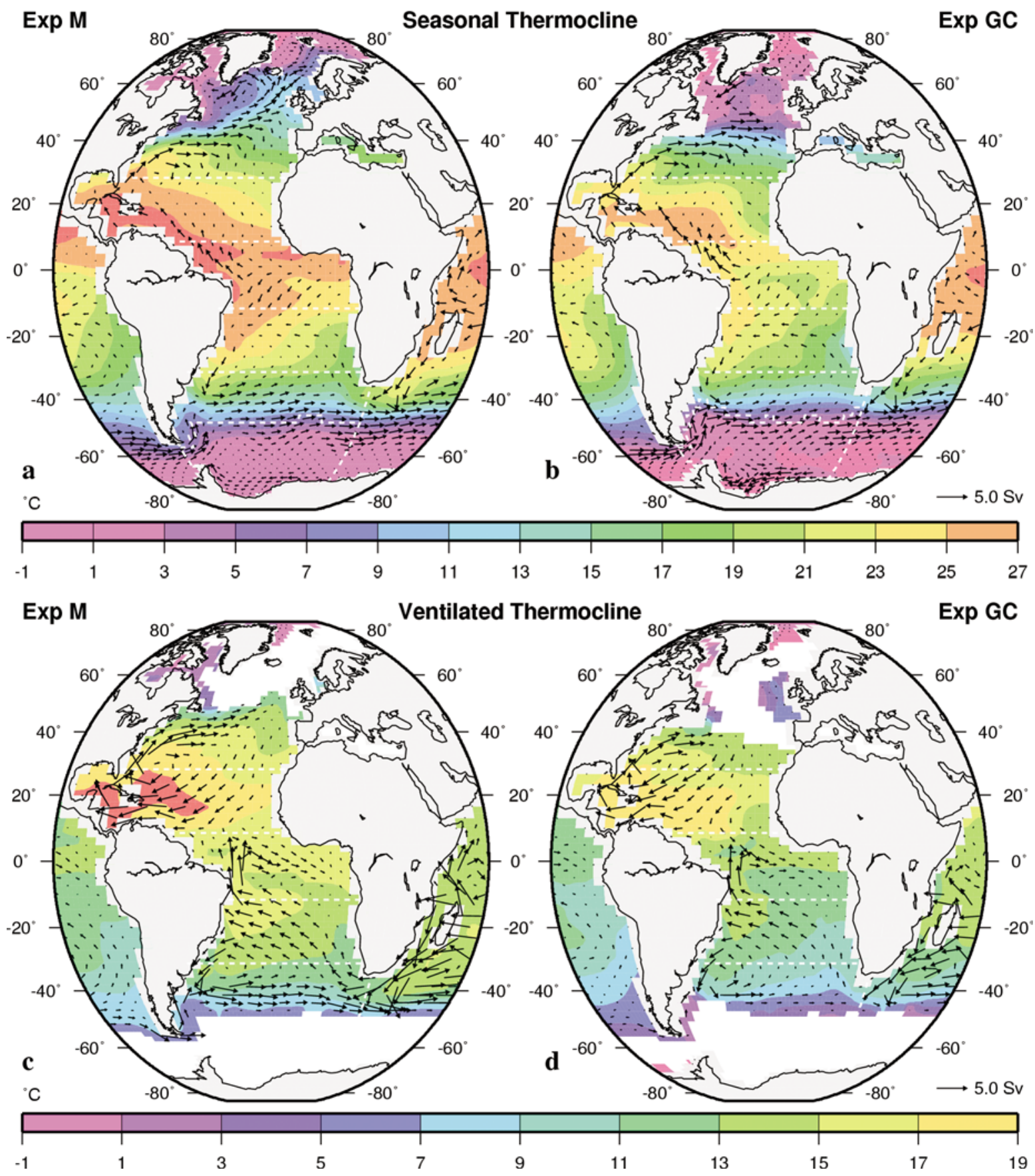

Fig. 9. Annual-mean horizontal volume transport $(\mathrm{Sv})$ and temperature $\left({ }^{\circ} \mathrm{C}\right)$, vertically averaged over the $(\mathbf{a}, \mathbf{b})$ seasonal thermocline, $(\mathbf{c}, \mathbf{d})$ ventilated thermocline, $(\mathbf{e}, \mathbf{f})$ intermediate water, $(\mathbf{g}, \mathbf{h})$ deep water and $(\mathbf{i}, \mathbf{j})$ bottom water layers. Left column: Modern (Experiment M). Right column: LGM (Experiment GC). For clarity, we show only one vector in two and arbitrarily truncate arrow lengths to that of the vector that is longer than $92 \%$ of all vectors. The water mass boundaries that define the respective layers are given in Table 5. Dashed white lines denote the zonal and meridional sections used in Figures 13-15. 

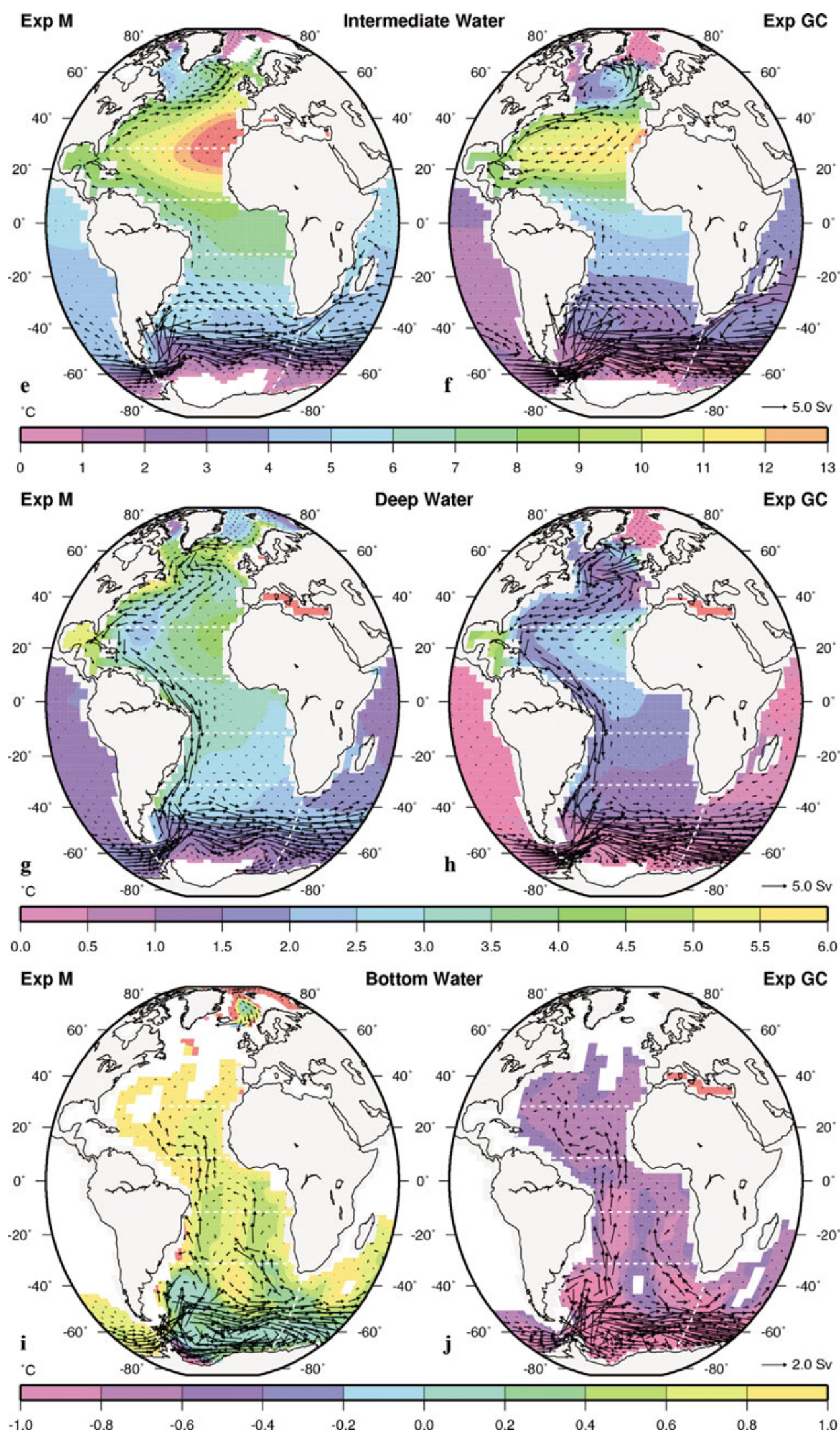

Fig. 9. cont. 


\section{Vertical Volume Transport}
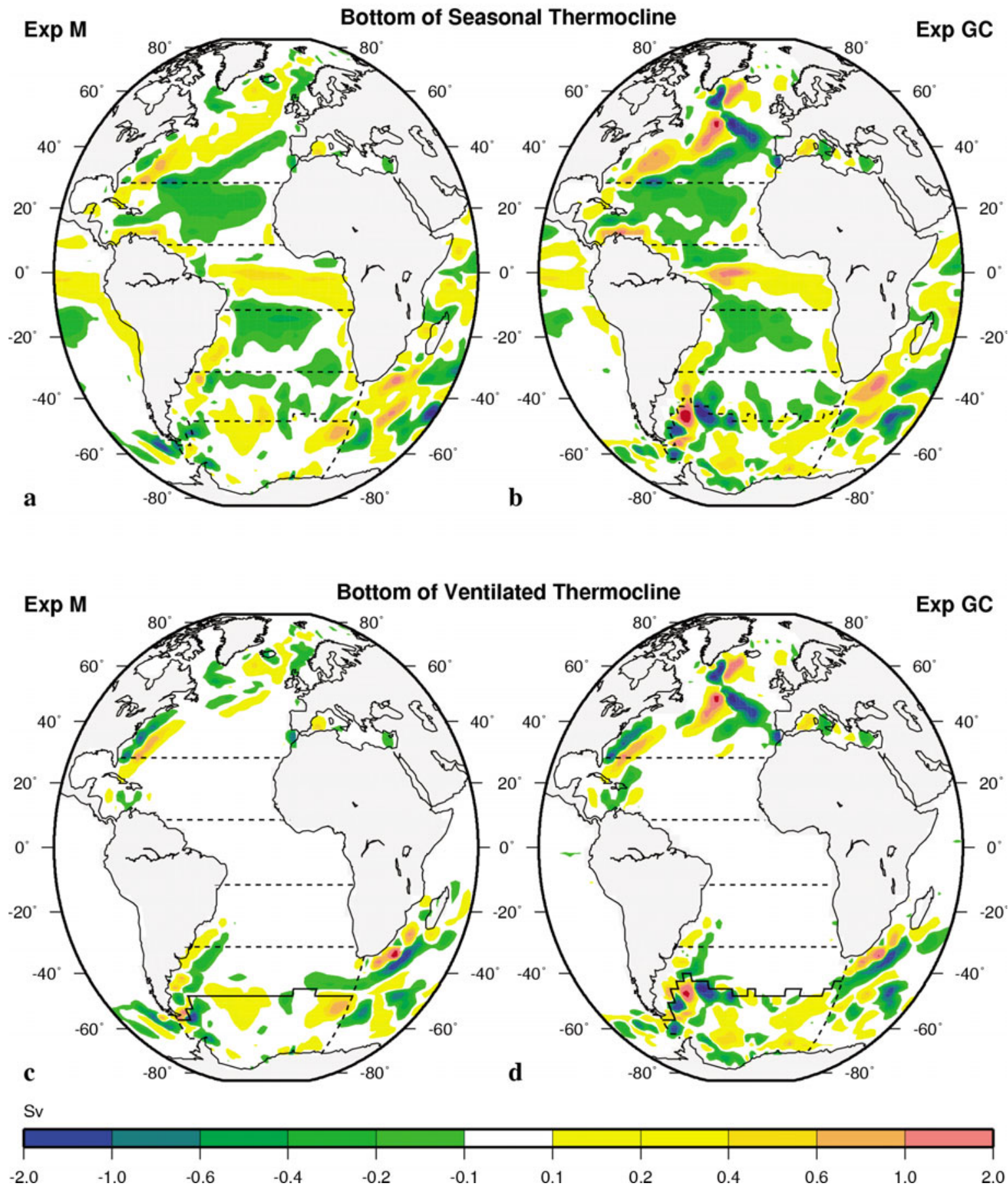

Fig. 10. Vertical volume transports $(\mathrm{Sv})$ at the base of the $(\mathbf{a}, \mathbf{b})$ seasonal thermocline, $(\mathbf{c}, \mathbf{d})$ ventilated thermocline, $(\mathbf{e}, \mathbf{f})$ intermediate water and (g,h) deep water layers. Left column: Modern (Experiment M). Right column: LGM (Experiment GC). Positive values (yellow to red) indicate upwelling, negative values (green to blue) indicate downwelling. Whenever a layer outcrops at high latitudes, the vertical volume transport at the base of next deeper layer is shown (cf. Figure 15). The solid lines in c-h indicate the outcrop of the respective layer in the Southern Ocean. The dashed lines denote the zonal and meridional sections used in Figures 13-15 (the southernmost dashed line in $a$ and $b$ reflects the outcrop of the ventilated thermocline layer below). 

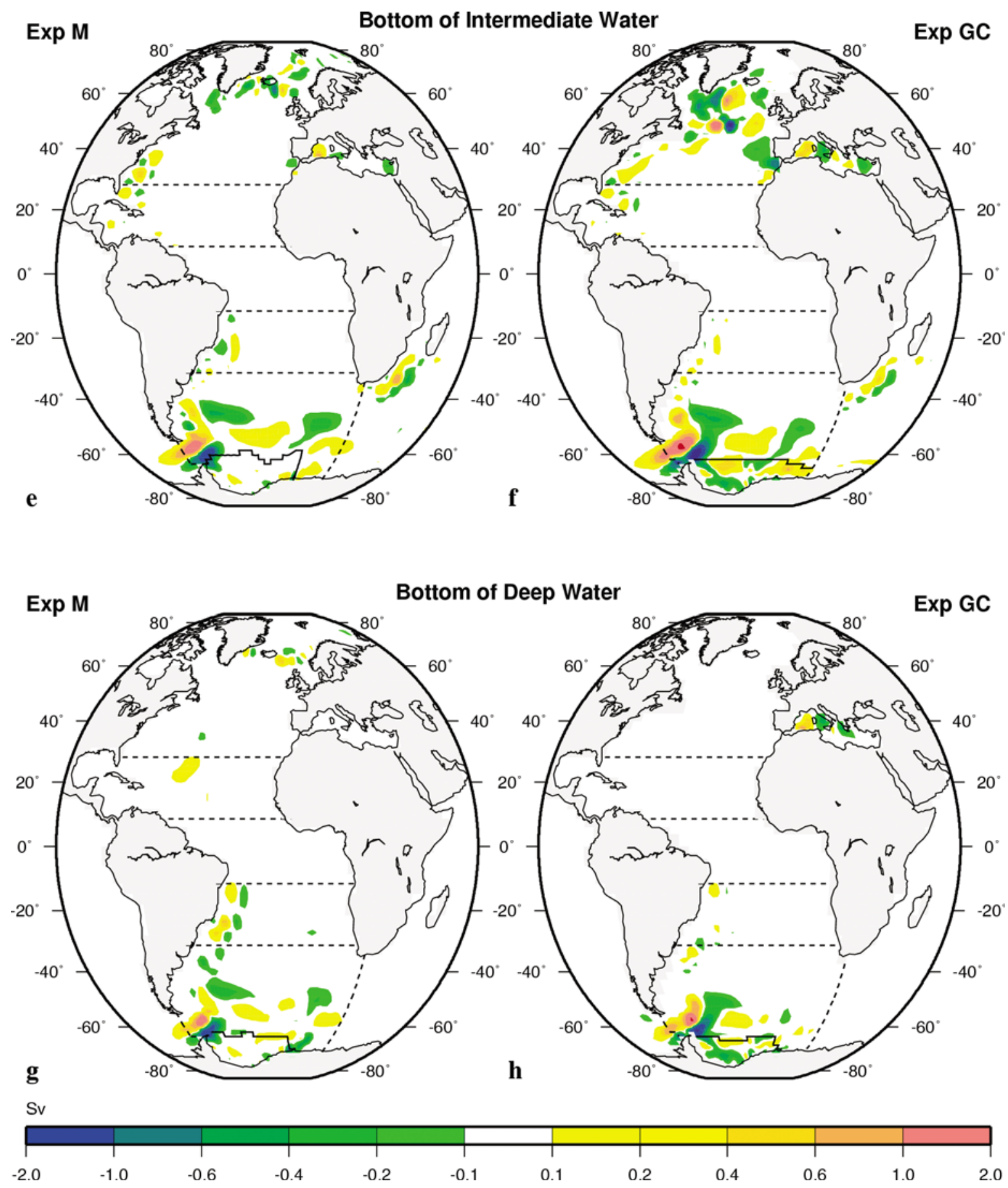

Fig. 10. cont. 
water at the western boundary, and none at the equator (Figure 10). In Experiment GC as compared to Experiment M, equatorial upwelling (between $5^{\circ} \mathrm{S}$ and $5^{\circ} \mathrm{N}$ ) into the mixed layer was stronger by a factor of 3 to 5 (Figure 10a). The equatorial downwelling was also more intense. Coastal upwelling at the LGM slightly increased in the southern Benguela System, but decreased in the northern Benguela System, consistent with the change in the Ekman pumping velocity (Figure 2). In the deeper layers, there was upwelling as well as downwelling south of $40^{\circ} \mathrm{S}$.

Figure 11 shows the meridional overturning circulation in the Atlantic Ocean. In addition to three shallow, wind-driven cells, there are two cells at depth indicating the formation and outflow of North Atlantic Deep Water (NADW) and the inflow of AABW. In Experiment M, $10 \mathrm{~Sv}$ of new NADW were formed in the northern North Atlantic Ocean, almost 4 of which originated from the Arctic Ocean. Only $1 \mathrm{~Sv}$ upwelled north of $30^{\circ} \mathrm{N}$ and $1 \mathrm{~Sv}$ upwelled at the equator, leaving $8 \mathrm{~Sv}$ for export across $30^{\circ} \mathrm{S}$. Experiment GC shows similar total rates of NADW formation and upwelling in the North Atlantic Ocean as Experiment M, but the formation was shifted to the south and split into two convection areas, one south of $50^{\circ} \mathrm{N}$, the other south of $70^{\circ} \mathrm{N}$. Thus, even under glacial conditions, about half of the NADW was formed at or slightly north of the Greenland-Iceland-Scotland ridge. In both Experiment $\mathrm{M}$ and Experiment GC, the inflow of AABW at $30^{\circ} \mathrm{S}$ amounted to $4 \mathrm{~Sv}$.

The meridional heat transport in the Atlantic Ocean was northward at all latitudes (Figures 12 and 13). The maximum occurred at about $28^{\circ} \mathrm{N}$ and amounted to $0.57 \mathrm{PW}$ in Experiment $\mathrm{M}$ and $0.55 \mathrm{PW}$ in Experiment GC. In the LGM case with the reduced Agulhas leakage, the northward heat transport in the South Atlantic Ocean was reduced. There was only a very small change of about $0.02 \mathrm{PW}$ in the cross-equatorial heat transport. However, northward of $40^{\circ} \mathrm{N}$, the decrease in Experiment $\mathrm{GC}$ as compared to Experiment $\mathrm{M}$ reached $0.1 \mathrm{PW}$.

\section{Atlantic Ocean Meridional Overturning Streamfunction}

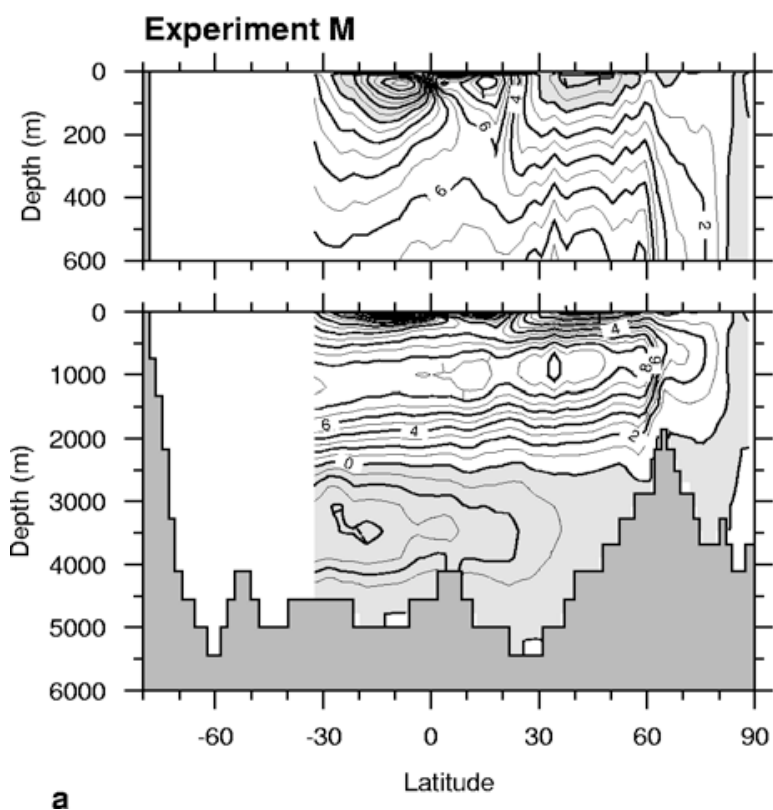

Experiment GC

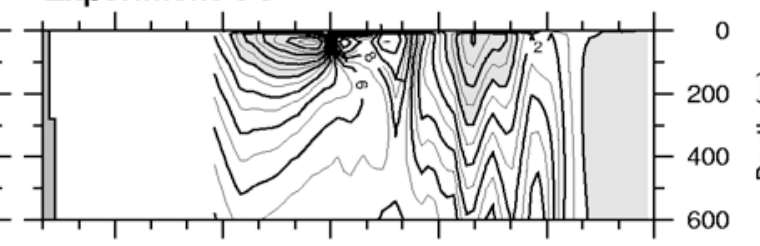

Fig. 11. Annual-mean meridional overturning streamfunction (Sv) for the Atlantic Ocean. a) Experiment M. b) Experiment GC. The contour interval is $1 \mathrm{~Sv}$. Light shading indicates negative contour levels and anti-clockwise circulation. No streamfunction can be defined at latitudes south of Cape of Good Hope where there is zonal exchange with the Pacific and Indian Oceans. 
Northward Heat Transport
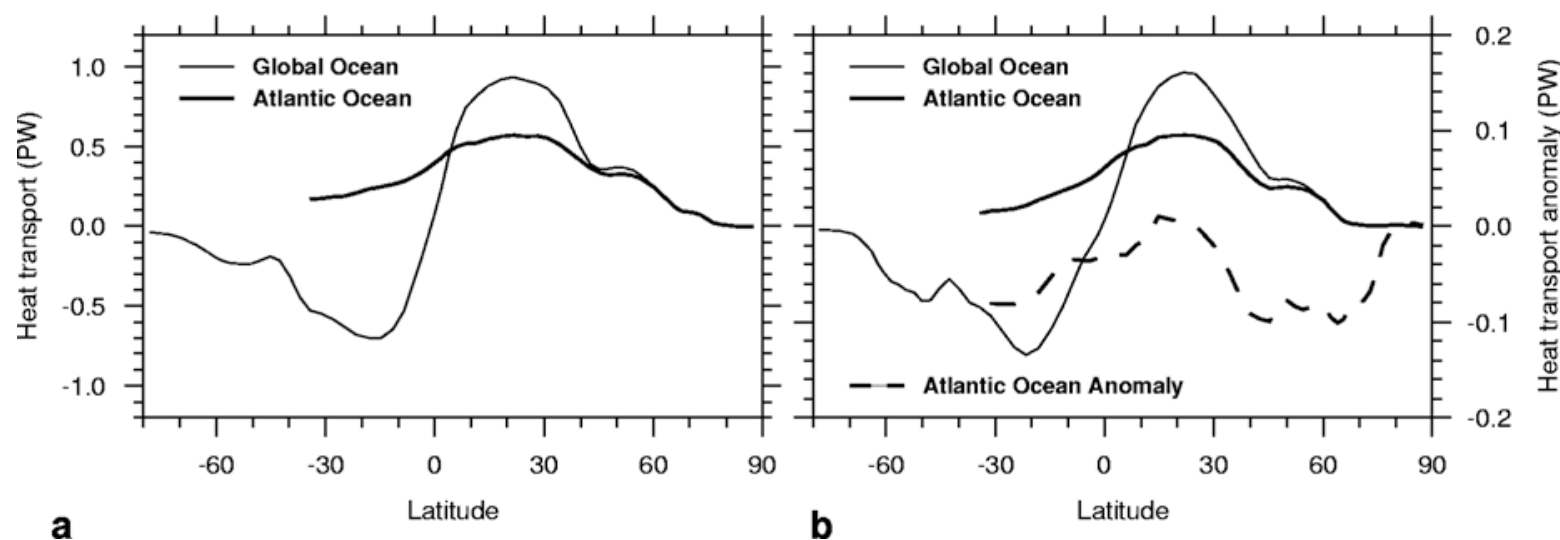

Fig. 12. Annual-mean zonally averaged northward heat transport (PW). a) Modern (Experiment M). b) LGM (Experiment GC). Thin solid line: global ocean, thick solid line: Atlantic Ocean, thick dashed line: Atlantic Ocean LGM anomaly.

\section{Total Depth-Integrated Volume and Heat Transports}
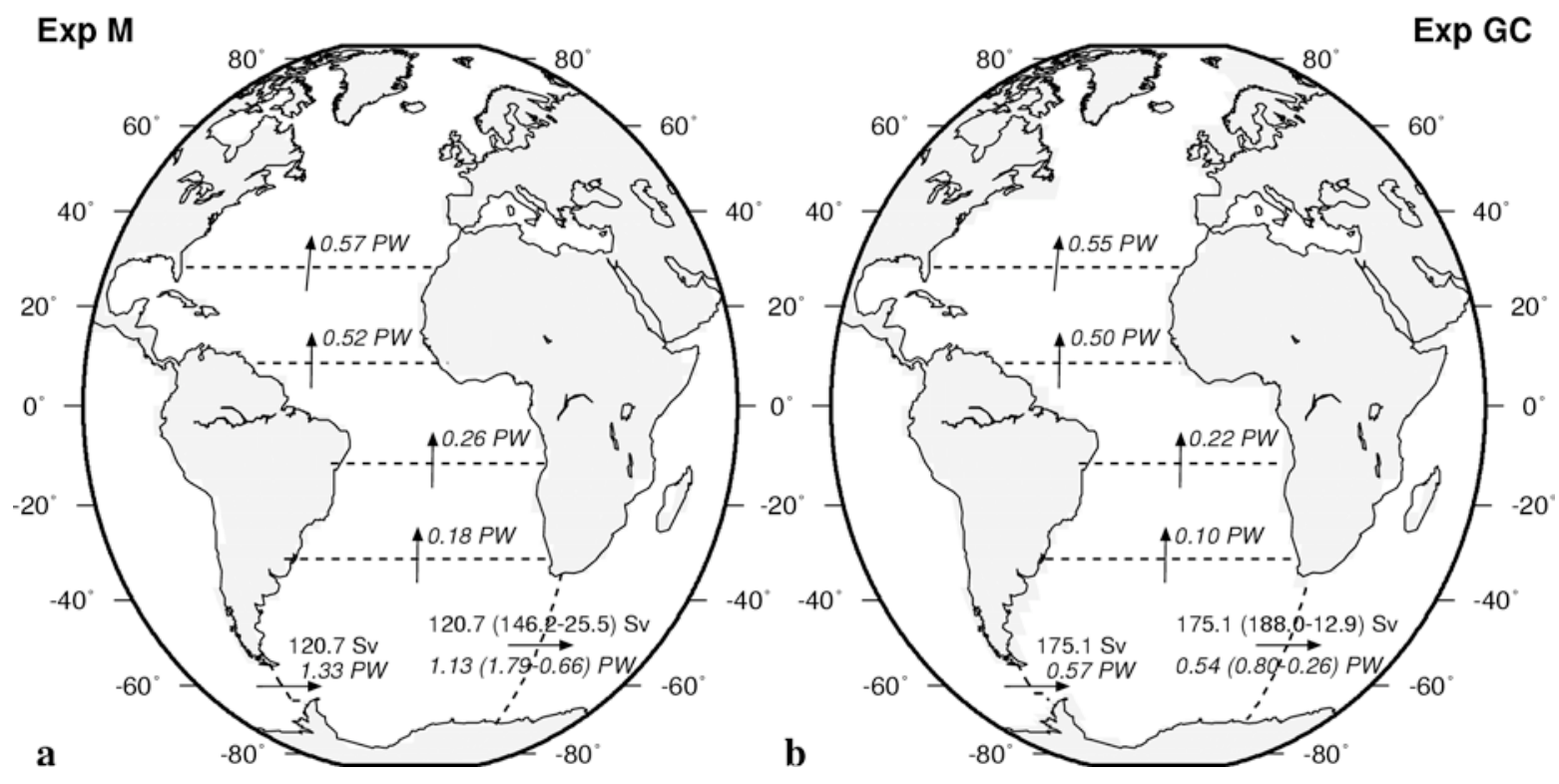

Fig. 13. Schematic representation of the simulated horizontal volume and heat transports, vertically integrated over the whole depth of the water column (cf. Sloyan and Rintoul 2001, Figure 2). a) Modern (Experiment M). b) LGM (Experiment GC). The dashed lines mark selected zonal sections at $\sim 30^{\circ} \mathrm{S}, \sim 11^{\circ} \mathrm{S}, \sim 8^{\circ} \mathrm{N}$ (close to classic hydrographic sections) and $\sim 24^{\circ} \mathrm{N}$ (near the southern tip of Florida), and meridional sections at $\sim 68^{\circ} \mathrm{W}$ (at Cape Horn) and $\sim 20^{\circ} \mathrm{E}$ (near Cape of Good Hope). Volume transports (Sv) are zero across the zonal sections because there is no advective flow through Bering Strait. Heat transports (PW) are relative to $0^{\circ} \mathrm{C}$. 
In addition to the heat transports across selected zonal sections at $31.17^{\circ} \mathrm{S}, 11.48^{\circ} \mathrm{S}, 8.55^{\circ} \mathrm{N}$ and $28.04^{\circ} \mathrm{N}$, Figure 13 indicates the volume and heat transports across the meridional sections at $68.4^{\circ} \mathrm{W}$ (at Cape Horn) and $21.6^{\circ} \mathrm{E}$ (near Cape of Good Hope) in the southern hemisphere (these model latitudes and longitudes are close to classic hydrographic sections at $30^{\circ} \mathrm{S}, 11^{\circ} \mathrm{S}, 8^{\circ} \mathrm{N}, 24^{\circ} \mathrm{N}, 68^{\circ} \mathrm{W}$ and $20^{\circ} \mathrm{E}$, e.g. Hall and Bryden 1982, Klein et al. 1995, Sloyan and Rintoul 2001). The air-sea heat flux in the South Atlantic Ocean south of $31.17^{\circ} \mathrm{S}$ was nearly balanced and amounted to $-0.02 \mathrm{PW}$ in Experiment $\mathrm{M}$ and $+0.07 \mathrm{PW}$ in Experiment GC. Thus the heat gained by the South Atlantic Ocean north of $31.17^{\circ} \mathrm{S}$ was mainly determined by the difference between the heat exported by the ACC and the heat imported by the Agulhas leakage. The heat exchanged between the South Atlantic and Indian Oceans via the Agulhas leakage decreased from about $0.66 \mathrm{PW}$ in Experiment $\mathrm{M}$ to about 0.26 $\mathrm{PW}$ in Experiment GC.

In Figure 14 we summarize the exact depthintegrated horizontal volume transports within the five layers shown in Figure 9 (cf. England and Garçon 1994 and Sloyan and Rintoul 2001 for similar diagrams of the present-day circulation in the South Atlantic Ocean), and Figure 15 details the vertical mass exchange between these different layers (cf. Sloyan and Rintoul 2001, Figure 13). The most prominent changes between the modern and the glacial experiment occured in the Drake Passage and south of Cape of Good Hope. In Experiment $\mathrm{M}$, the inflow of Indian Ocean water via the Agulhas leakage accounted for $28 \%$ of the transport of the Benguela Current in the seasonal thermocline (1.5 out of $5.4 \mathrm{~Sv})$. In the ventilated thermocline, this fraction increased to $55 \%$ (6 out of $11 \mathrm{~Sv})$, and in the Intermediate Water eventually reached as much as $87 \%$ ( 6 out of $6.9 \mathrm{~Sv}$ ). In total, $60 \%$ of the Benguela Current in Experiment $M$ were fed by the Agulhas leakage. In Experiment GC, the respective numbers were $20 \%$ (seasonal thermocline, 0.7 out of $3.5 \mathrm{~Sv}$ ), $11 \%$ (ventilated thermocline, 1 out of $9.5 \mathrm{~Sv}$ ), and $38 \%$ (Intermediate Water, 4.5 out of $11 \mathrm{~Sv}$ ), which summed up to $25 \%$ over the three levels, leaving the mixture of waters from Drake Passage, from the Brazil Current, and from the upwelling around $60^{\circ} \mathrm{S}$ (cf.
Figure 15) as the dominant source for the water masses in the southern Benguela system. In this experiment, the Benguela Current was slightly stronger than in Experiment $\mathrm{M}$ and stayed closer to the coast.

\section{Oxygen-18}

Sea-water oxygen-18 $\left(\delta^{18} \mathrm{O}_{\mathrm{w}}\right)$ was a passive tracer in our ocean model, restored to the same sparse and scattered modern annual-mean observations in all experiments. For the sea surface, this treatment was similar to the horizontal interpolation scheme by Takahashi et al. (1997), but it allowed for a vertical exchange with the deep ocean. Accordingly, the resulting sea-surface distribution in Experiment $\mathrm{M}$ shows a general agreement between model and data (Figure 16). In Experiment $\mathrm{GC}$, there were large local changes, particularly in upwelling areas (cf. Figure $2 \mathrm{c}$ and d) where the restoring boundary condition was less effective and the characteristics of the upwelled water dominated. In the south-eastern South Atlantic Ocean, the upwelled water was depleted in oxygen- 18 by $0.4 \%$ and originated from the western South Atlantic Ocean rather than the Indian Ocean (cf. Figure 9). In the North Atlantic Ocean, the changes in the subtropical gyre reflected the more zonallyoriented Gulf Stream and the stronger recirculation.

Despite identical $\delta^{18} \mathrm{O}$ restoring data, our model experiments developed distinctly different $\delta^{18} \mathrm{O}_{\mathrm{w}}$ patterns with depth, indicating changes in the formation, transport and mixing of the various water masses. In the control run (Figure 17a) there were extremely light values in the high latitudes of the Atlantic Ocean, below $-0.2 \%$ at the surface, that influenced the oxygen isotope ratios of the underlying bottom waters. Consequently, the deep ocean was filled by light AABW $<0 \%$ and only slightly heavier water north of the Greenland-Scotland ridge. These light values were contrasted by higher ratios $>0.2 \%$ in the NADW and in the ventilated thermocline, where more than $1.1 \%$ were reached at about $30^{\circ} \mathrm{N}$. AAIW was characterized by values around $0.1-0.2 \%$.

All glacial experiments were marked by considerably heavier values around $0.5 \%$ within the NADW tongue, which yielded a much sharper 


\section{Exact Depth-Integrated Volume Transports}
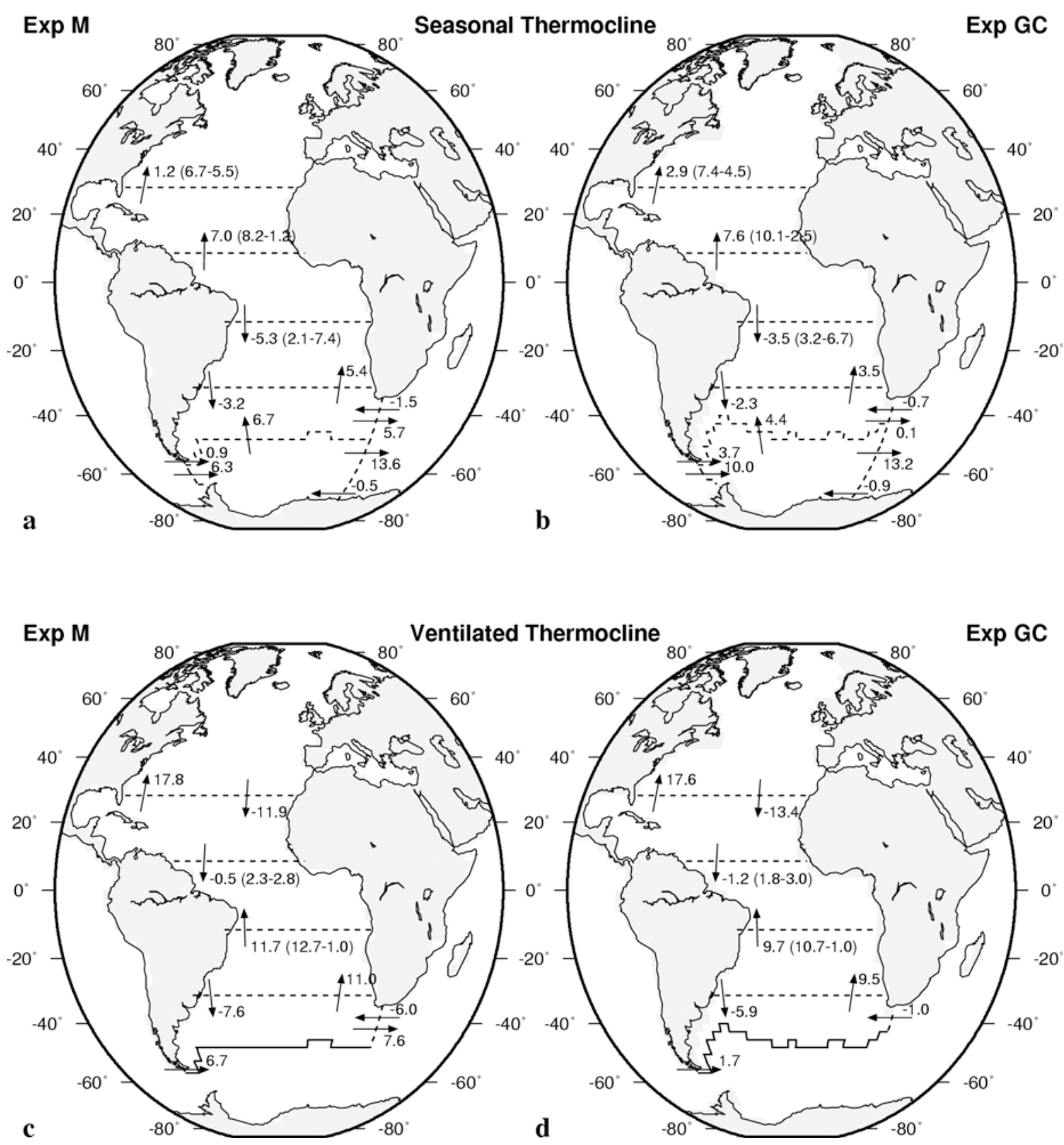

Fig. 14. Schematic representation of the simulated horizontal volume transports (Sv), vertically integrated over the $(\mathbf{a}, \mathbf{b})$ seasonal thermocline, $(\mathbf{c}, \mathbf{d})$ ventilated thermocline, $(\mathbf{e}, \mathbf{f})$ intermediate water, $(\mathbf{g}, \mathbf{h})$ deep water and $(\mathbf{i}, \mathbf{j})$ bottom water layers (cf. England and Garçon 1994, Figure 11, and Sloyan and Rintoul 2001, Figure 5). Left column: Modern (Experiment M). Right column: LGM (Experiment GC). The water mass boundaries that define the respective layers are given in Table 5. The solid lines in c-h indicate the outcrop of the respective layer in the Southern Ocean. The dashed lines mark the same zonal and meridional sections as in Figure 13. 
$\operatorname{Exp} M$

Intermediate Water

Exp GC
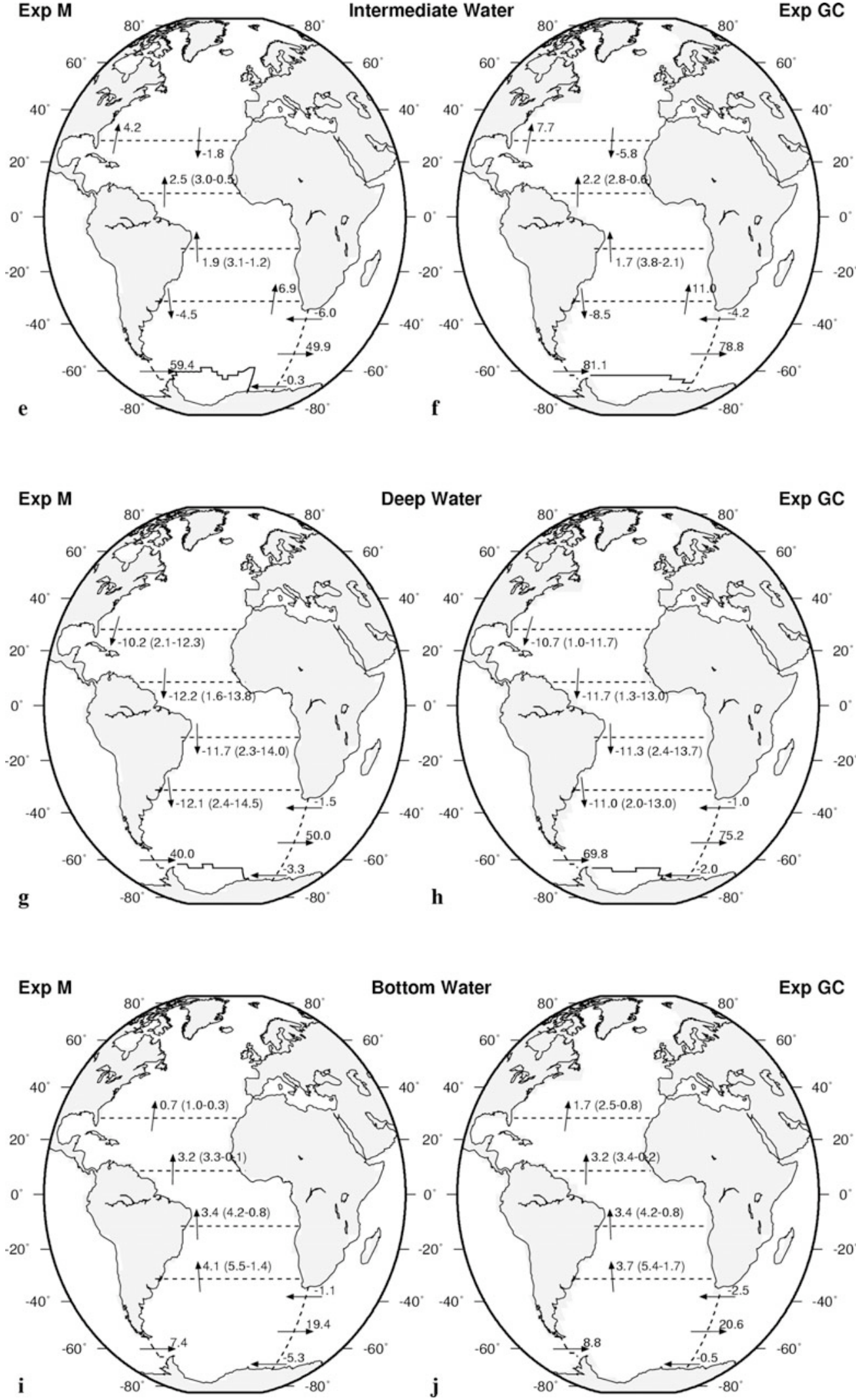

Fig. 14. cont. 


\section{Atlantic Ocean Meridional and Vertical Volume Transports}

\section{Experiment M}
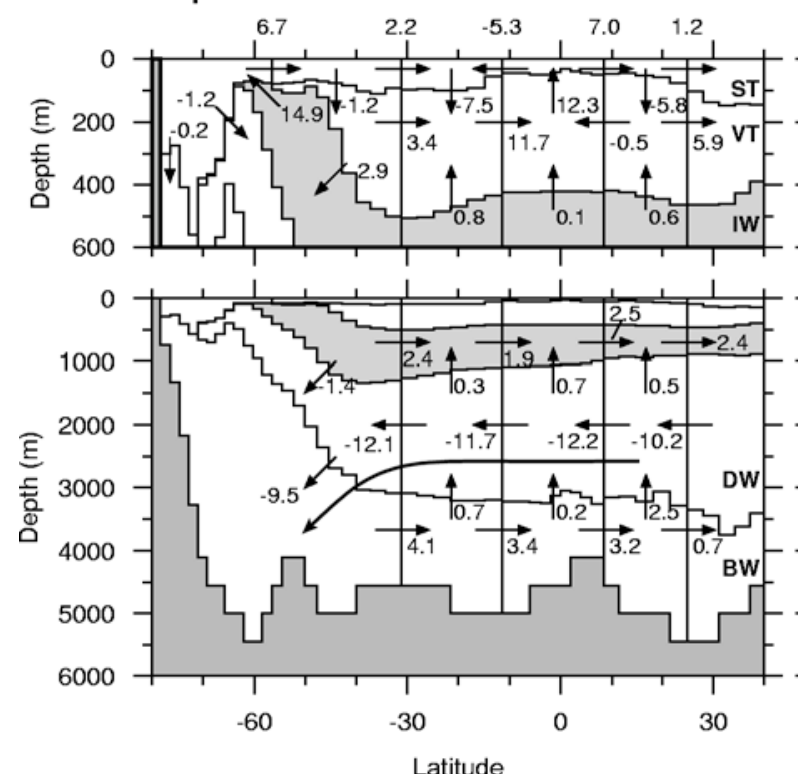

a
Experiment GC

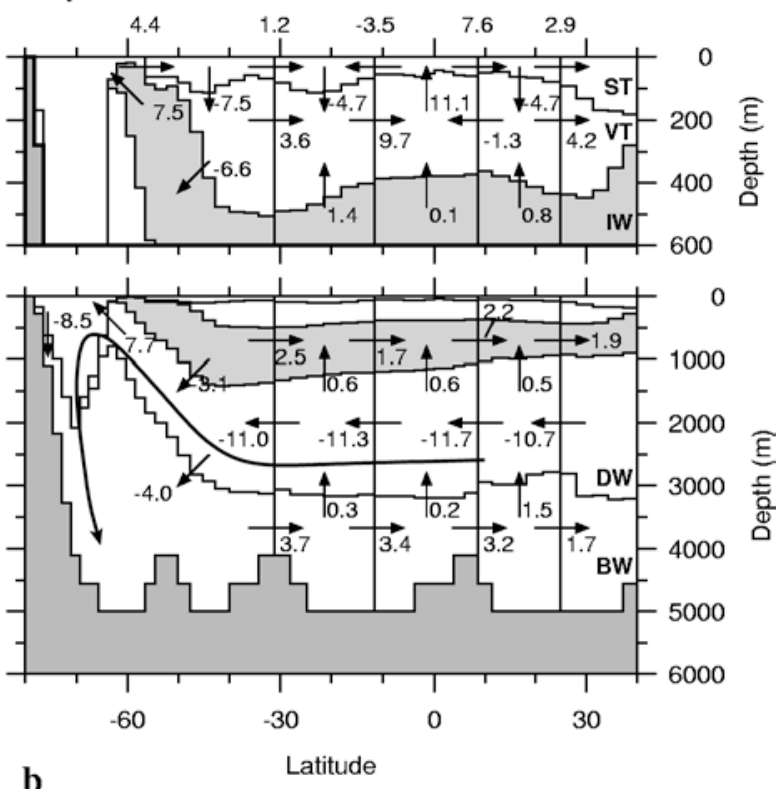

Fig. 15. Schematic five-layer view of the simulated annual-mean meridional overturning circulation (Sv) for the Atlantic Ocean (cf. Sloyan and Rintoul 2001, Figure 13). a) Modern (Experiment M). b) LGM (Experiment GC). The five layers are the seasonal thermocline (ST), ventilated thermocline (VT), intermediate water (IW), deep water (DW) and bottom water (BW). For better orientation, the intermediate water layer is shaded in both the upper (0$600 \mathrm{~m}$ depth) and lower panels (surface to bottom). The long arrows indicate the path taken by the deep water flow.

contrast to the almost unaltered AAIW isotope ratios. In the deep polar North Atlantic Ocean, there were higher values $>0.5 \%$ as well, separated by a narrow band of $0.1-0.2 \%$ from the subpolar Atlantic Ocean.

AABW experienced drastic changes in the course of the changing haline boundary condition in the Weddell Sea. Experiments GA and GB yielded $\delta^{18} \mathrm{O}_{w}$ values that were increased with respect to Experiment $\mathrm{M}$ and reached up to to $0.3 \%$ o (GA) and $0.1 \%$ o (GB). In Experiment GC, the $\delta^{18} \mathrm{O}_{\mathrm{w}}$ values of AABW $\delta^{18} \mathrm{O}_{\mathrm{w}}$ turned negative and were comparable to those of Experiment $M$.

The distribution of calcite oxygen-18 $\left(\delta^{18} \mathrm{O}_{c}\right)$ in equilibrium with ambient seawater (Figure 18) was computed from the modeled temperature and $\delta^{18} \mathrm{O}_{\mathrm{w}}$ fields and the paleotemperature equation by Mulitza et al. (2003), ignoring any 'vital' or explicit 'ice-volume' effects. It is largely a function of temperature with depth, with the lightest values in the upper ocean. As compared to the $\delta^{18} \mathrm{O}_{w}$ distribution, the AAIW tongue almost vanished in Experiment $\mathrm{M}$ and was much less prominent in the glacial experiments.

\section{Discussion}

\section{Hydrology}

The vertically averaged temperature and salinities for the Atlantic Ocean $\left(4.16^{\circ} \mathrm{C}, 34.86\right)$ and the global ocean $\left(3.73^{\circ} \mathrm{C}, 34.65\right)$ in Experiment $\mathrm{M}$ are much closer to the present-day observations than in the control experiments of Paul et al. (1999) and Schäfer-Neth and Paul (2001). This reflects the more realistic representation of the thermocline, intermediate and deep waters in our present configuration of the MOM, which is mainly due to the low vertical diffusion and the isopycnal mixing parameterization that overcomes the warm and 


\section{Sea Surface $\delta^{18} 0$ of Sea-Water}

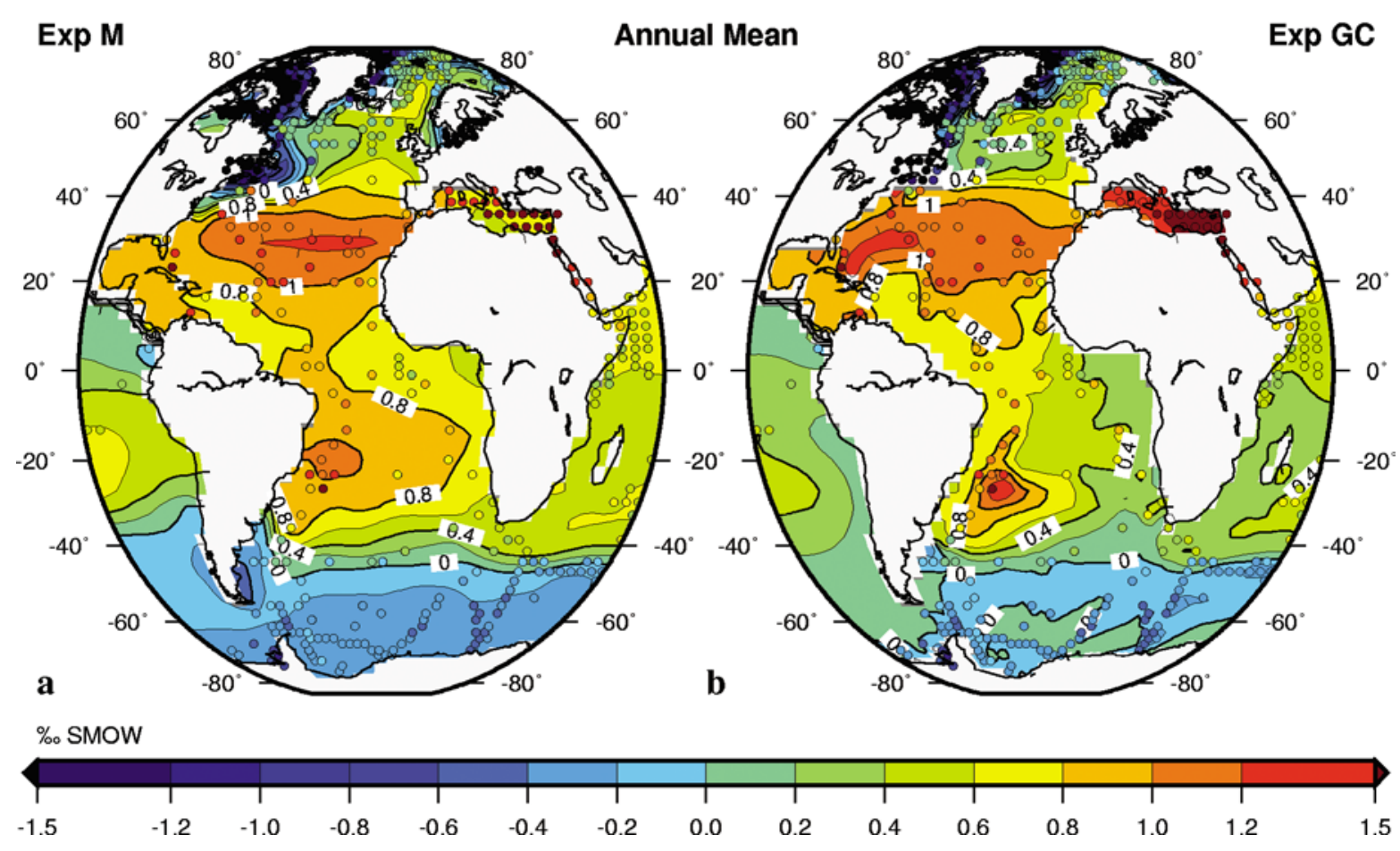

Fig. 16. Sea-surface distribution of annual-mean sea-water $\delta^{18} \mathrm{O}(\% \mathrm{~s}$ SMOW) for the Atlantic Ocean. a) Modern (Experiment M). b) LGM (Experiment GC). Circles denote observed present-day annual-mean sea-water $\delta^{18} \mathrm{O}$ from the GISS database (Schmidt et al. 1999). The contour interval is $0.2 \%$.

fresh bias of the older simulations with the MOM and LSG models.

A change in the global mean salinity by 1.35 to 1.46 corresponds to a change in relative mean sea level of about $130 \mathrm{~m}$, which is close to recent reconstructions (Clark and Mix 2002). In spite of the reorganization of the deep ocean stratification, the SST changed only very little from Experiment GA to GC. The SSS changed only in the Weddell Sea. This is a peculiarity of the restoring boundary condition that tries to maintain the prescribed sea-surface conditions even against changes of the largescale circulation.

Following the recipe outlined in Section 2.3, we obtained $\sigma_{0}=26.9 \mathrm{~kg} \mathrm{~m}^{-3}$ as the lower boundary of the ventilated thermocline in Experiment M (Table 5). This compares well with density criteria derived from modern observations which range be- tween 26.8 and $27.1 \mathrm{~kg} \mathrm{~m}^{-3}$. For example, Williams et al. (1995) and Schmid et al. (2000) use $\sigma_{0}=$ $27.0 \mathrm{~kg} \mathrm{~m}^{-3}$. Our slightly lower value may reflect that in Experiment $\mathrm{M}$ the salinity (and hence the density) of the upper Atlantic Ocean is somewhat too low (not shown).

In our model, the outcrop locations of the thermocline isopycnal surfaces in the North Atlantic Ocean shifted from about $40^{\circ}-55^{\circ} \mathrm{N}$ in Experiment $\mathrm{M}$ to about $35^{\circ}-45^{\circ} \mathrm{N}$ in Experiments GA-GC (Figure 5). As a net result, the thermocline waters cooled by $2-3^{\circ} \mathrm{C}$ in the North Atlantic Ocean and $4-5^{\circ} \mathrm{C}$ in the South Atlantic Ocean. The general cooling and shoaling of the ventilated thermocline is in agreement with the reconstruction by Slowey and Curry (1995), which is based on large $\delta^{18} \mathrm{O}$ increases in benthic foraminifera on the margins of the Little and Great Bahama Banks. However, we 


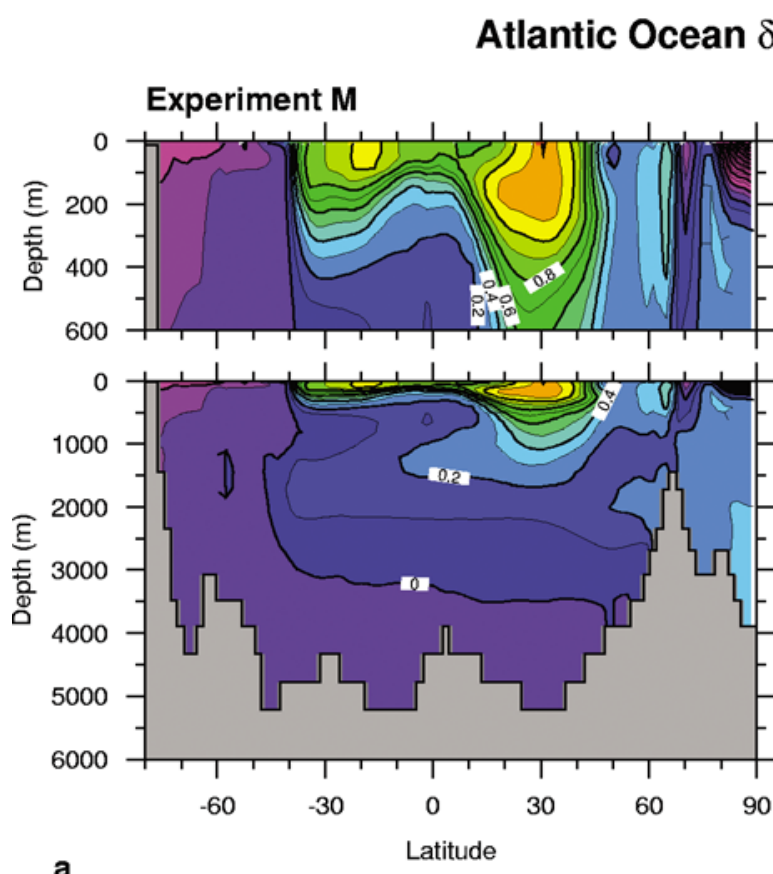

a
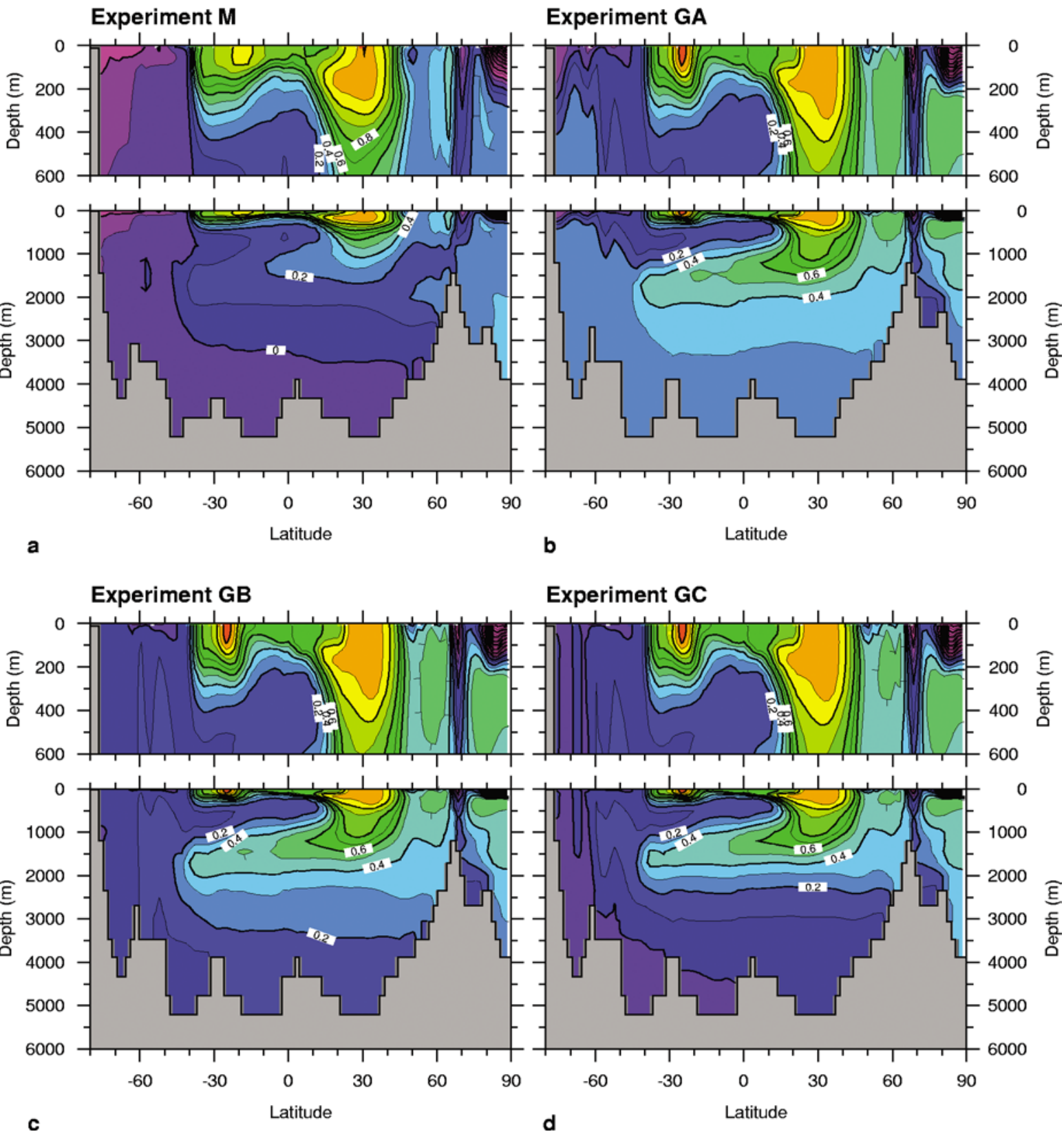

Experiment GC

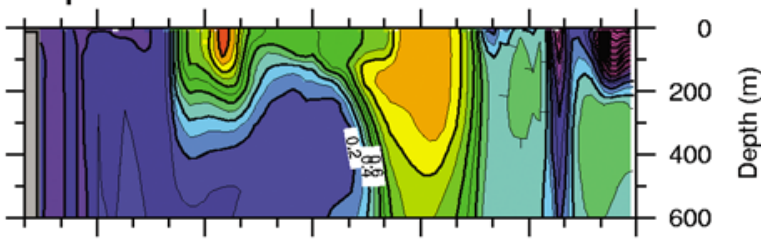

Fig. 17. Annual-mean distribution of sea-water $\delta^{18} \mathrm{O}(\% \mathrm{SMOW})$ along the Western Atlantic Ocean transect. a) Experiment M. b) Experiment GA. c) Experiment GB. d) Experiment GC. The contour interval is $0.1 \%$.

do not find a shallower ventilated thermocline precisely at the location of the Bahama banks. There are two possible reasons for this: First the Caribbean is influenced by complex topography, which is only crudely resolved in our model. Second, the western boundary current region may be governed by different dynamics than the interior of the subtropical gyre.

The net annual ice export of the inner Weddell Sea south of $63^{\circ} \mathrm{S}$ has been estimated as $50 \pm 19$ $\mathrm{mSv}$ (Harms et al. 2001) from a twenty-year deployment of upward-looking sonar systems and 


\section{Atlantic Ocean $\delta^{18} \mathrm{O}$ of Foraminiferal Carbonate}

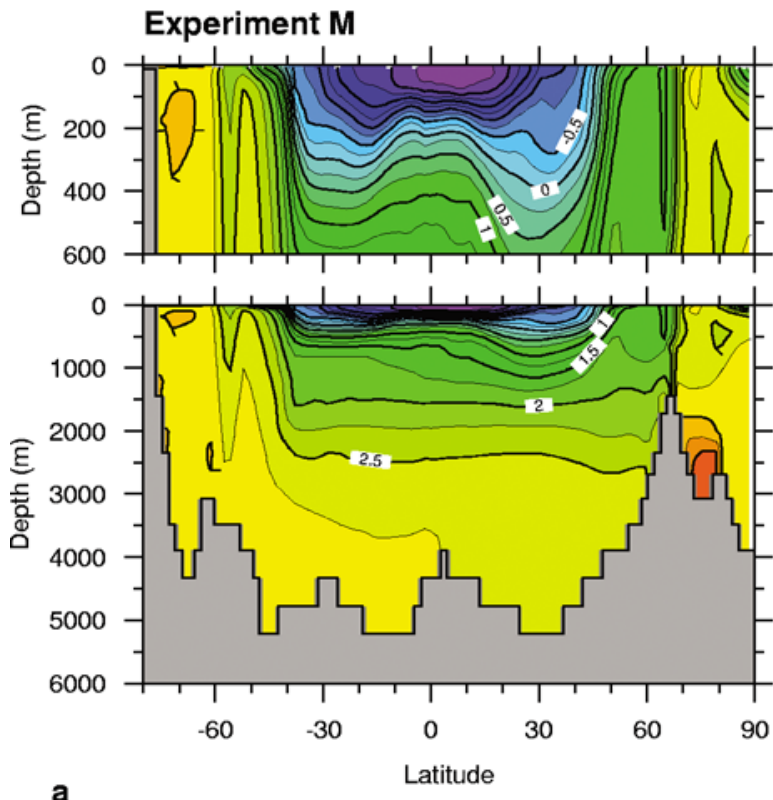

\section{Experiment GA}

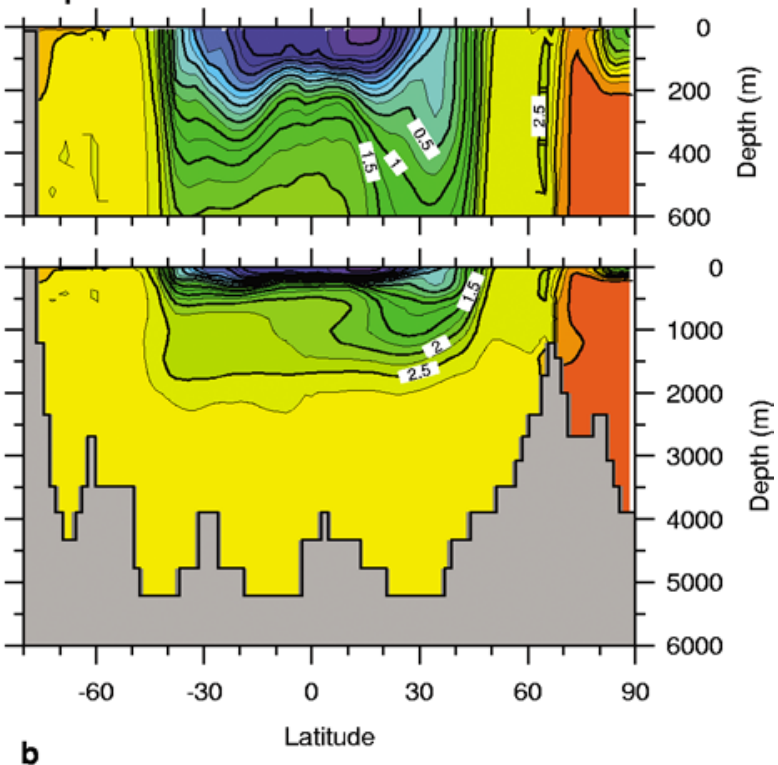

Experiment GB

Experiment GC
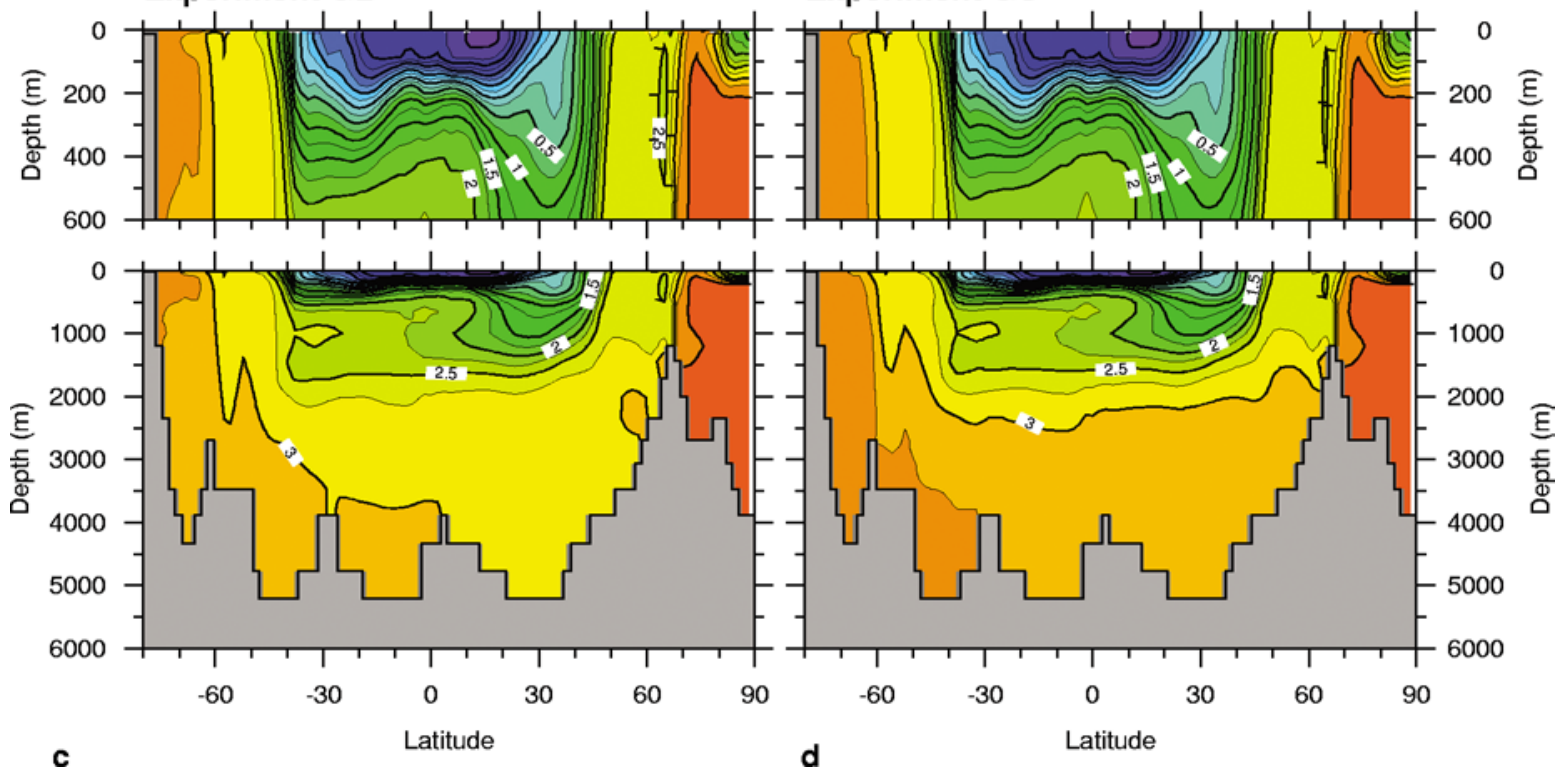

Fig. 18. Annual-mean distribution of calcite $\delta^{18} \mathrm{O}(\% \mathrm{PDB})$ in equilibrium with ambient seawater along the Western Atlantic Ocean transect. a) Experiment M. b) Experiment GA. c) Experiment GB. d) Experiment GC. The contour interval is $0.25 \%$.

satellite microwave measurements. Timmermann et al. (2001) use these data to validate their coupled sea ice-ocean model, which yields an ice export of $42 \pm 25 \mathrm{mSv}$. According to this model, the freshwater loss due to sea-ice formation roughly balances ice-shelf basal melting and net precipitation and amounts to $5 \pm 13 \mathrm{mSv}$ in the annual mean. In our case, the net freshwater loss through the surface of the inner Weddell Sea may be inferred from the implied salinity fluxes due to the SSS re- 
storing boundary condition. For Experiment M, we find nearly $4.9 \mathrm{mSv}$ (Table 3), which is in good agreement with the results of Timmermann et al. (2001). However, it should be kept in mind that the available observations are the residuum of several large terms of different signs, namely snowfall/precipitation, glacial melt from the ice shelves and ice advection, which easily exceed the net freezing rate by an order of magnitude. This is even more the case for the seasonal variations and clearly evident from the large error margin of the model estimate $(5 \pm 13 \mathrm{mSv})$. As Timmermann et al. (2001) conclude, sea-ice formation appears to be a necessary condition for the renewal of AABW, and any changes in the Weddell Sea freshwater budget have a significant effect on the global circulation, a result that is also born out by our series of glacial experiments (GA-GC). As can be seen from Table 3, there was a net freshening of the Weddell Sea in Experiments GA and GB. Due to the upwelling of salty NADW, the restoring to lower SSS implied a net melting of sea ice instead of sea ice formation. Only in Experiment GC, the net freshwater flux turned negative again, which indicated the net export of sea ice (freshwater) from the inner Weddell Sea and corresponded to a net formation of sea-ice, at a rate vastly increased with respect to our control run. This nonlinear dependence of the implied sea ice formation on the Weddell Sea sea-surface salinity indicates that between Experiments GB and GC a threshold was passed, beyond which the water column turned unstable and convection was triggered.

\section{Circulation}

The transport of the ACC in Experiment M was $121 \mathrm{~Sv}$, which was close to the observed value (e.g. $130 \pm 20 \mathrm{~Sv}$ - Witworth and Peterson 1985) and much smaller than the value of $225 \mathrm{~Sv}$ in the study by Paul et al. (1999). The improvement was due to the effects of the isopycnal mixing and mesoscale eddy transport parameterizations on the isopycnal form stress in the ACC. The transport rates of the western boundary currents tended to be lower than observed, mainly because of the relatively coarse zonal resolution of our ocean model.
This was particularly true for the Gulf Stream transport of $20 \mathrm{~Sv}$ that was only half of the observed strength, and for the northern subpolar gyre. With this exception, the horizontal mass transports of our control run agreed reasonably well with the observed current strengths (e.g. England and Garçon 1994).

The cooling of the high northern latitudes and the associated changes in the wind stress distribution (Figure 2b) caused the North Atlantic Drift to take a more easterly direction (Figure 9a), which is a common finding in many modeling studies of the LGM ocean. Changes in the wind stress distribution in the Brazil Basin as indicated by Figure $2 b$ and the southward shift of the zero line of Ekman pumping as implied by Figure $2 \mathrm{c}$ also led to the larger Brazil Current transport and southward shift of the Brazil and Malvinas Currents by one gridpoint, in spite of the strengthening of the ACC.

In contrast to previous modeling studies of the glacial ocean, we used low vertical diffusion in the upper $2000 \mathrm{~m}$ and a relatively high vertical resolution, which yielded a realistic representation of modern AAIW. In Experiment M, the associated $\delta^{18} \mathrm{O}_{\mathrm{w}}$ minimum (closely related to a salinity minimum, not shown) could be traced as far as $10^{\circ} \mathrm{N}$; it was $750 \mathrm{~m}$ deep at $40^{\circ} \mathrm{S}$ and gradually rose until it reached a depth of $500 \mathrm{~m}$. Furthermore, the low vertical diffusion also yielded very little upwelling into the tropical thermocline in all experiments (Figure 10), thus the transport of NADW across $30^{\circ} \mathrm{S}$ was only 1-2 Sv lower than across $30^{\circ} \mathrm{N}$ (Figure 11). In this respect, the meridional circulation resembled the 'reconfigured conveyor belt' of Toggweiler and Samuels (1995a) with most of the deep water upwelling in the Southern Ocean.

We note that the results in Figure 9 are sensitive to the choice of the water mass boundaries. However, the barrier layer thickness provides a mean to determine the base of the ventilated thermocline in an objective way, for present time as well as during the LGM, independently of the actual sea-water density that may be subject to global and local changes.

An increase in Weddell Sea sea-surface salinity leads to a positive density anomaly, which is transported into the deep ocean. Accordingly, the meridional density gradient grew from Experiment 
GA to Experiment GC, and the ACC strengthened (cf. Borowski et al. 2002). In Experiment GC, the additional 1.0 SSS anomaly imposed on the Weddell Sea accelerated the ACC to almost $150 \%$ of its modern transport, as compared to Experiment $\mathrm{M}$ (Table 4). At the same time, the ACC broadened and its northern boundary approached Cape of Good Hope. The southward penetration of the Agulhas Current was reduced, and consequently, in Experiment GC the Agulhas leakage was diminished to only $40 \%$ of that found in Experiment $\mathrm{M}$ or GA, in agreement with the theoretical and modeling studies reviewed by de Ruijter et al. (1999). The model resolution was too coarse to generate baroclinic eddies such as Agulhas rings, thus only a broad westward advective transport was simulated, plus some westward diffusive transport of heat due to the isopycnal and eddy transport parameterizations (cf. England and Garçon 1994).

The maximum of the meridional heat transport in the Atlantic Ocean (Figures 12 and 13) amounted to only half of the estimates by e.g. Hall and Bryden (1982) and Klein et al. (1995). This could also be due to the coarse horizontal resolution of our model, which yielded a weak Gulf Stream with only half the observed transport. The injection of warm subtropical Indian Ocean Water into the southeastern corner of the Atlantic Ocean contributed significantly to the northward heat transport across $30^{\circ} \mathrm{S}$ (cf. Gordon 1986). Our value of 0.66 PW for the zonal heat transport by the Agulhas Current at $20^{\circ} \mathrm{E}$ in Experiment $\mathrm{M}$ compares well with the high-resolution model results of Thompson et al. (1997, -0.51 PW) and Biastoch and Krauss (1999, 0.87 PW). In Experiment GC, the same value was reduced to $0.26 \mathrm{PW}$ or $40 \%$, in agreement with the reduction in the volume transport associated with the Agulhas leakage. Similarly, our values for the integrated heat fluxes across the meridional sections at $68^{\circ} \mathrm{W}$ and $20^{\circ} \mathrm{E}$ (Figure 13) come close to those derived from present-day hydrographic data (1.41 and 1.19 PW according to Sloyan and Rintoul 2001), but are too small across the zonal section at $30^{\circ} \mathrm{S}$ (compared to $0.28 \mathrm{PW}$ after Sloyan and Rintoul 2001).

Since $60 \%$ of the water flowing northwestward with the Benguela Current stemmed from the
Agulhas Current, the warm water route proposed by Gordon (1986) dominated the NADW return flow in Experiment M. In contrast, in Experiment GC only $25 \%$ of the Benguela Current waters were of Indian Ocean origin, which indicates that the cold water route suggested by Rintoul (1991) became the main path for NADW renewal. We note that in our prognostic model the warm water path could be reconciled with a realistic transport of the ACC, which was not possible in the inverse model of Rintoul (1991). Consistent with the cold water path, a significant amount (14.9 Sv in Experiment $\mathrm{M}$ and 7.5 Sv in Experiment GC) of intermediate water that entered through Drake Passage was modified to thermocline water in the southeast Atlantic Ocean (Figure 15 - cf. England and Garçon 1994).

In Experiments $\mathrm{M}$ and $\mathrm{GC}$, the Atlantic Ocean as a whole converted about the same amount of thermocline and intermediate water to deep and bottom water. Experiment $M$ yielded an inflow from the Pacific Ocean of $73 \mathrm{~Sv}$ in the upper three levels (seasonal thermocline, ventilated thermocline and intermediate water), but only $47 \mathrm{~Sv}$ in the lower two levels (deep water and bottom water). For the outflow to the Indian Ocean, the respective transports were $62 \mathrm{~Sv}$ and $58 \mathrm{~Sv}$. The net downwelling in the Atlantic Ocean of about $11 \mathrm{~Sv}$ was roughly equal to the rate of NADW formation (Figure 11). Except for higher horizontal transports with the ACC (96 Sv and $79 \mathrm{~Sv}$ inflow, $85 \mathrm{~Sv}$ and $90 \mathrm{~Sv}$ outflow, $11 \mathrm{~Sv}$ downwelling), this scenario applies as well to Experiment GC.

However, in the Southern Ocean, the path taken by the deep water flow was quite different in the two experiments (bold arrows in Figure 15): In Experiment M, most of the NADW directly joined the AABW at about $50^{\circ} \mathrm{S}$, but in Experiment GC, it first upwelled into the seasonal thermocline and then downwelled in the Weddell Sea to contribute to the formation of $\mathrm{AABW}$, to eventually fill the deep Atlantic and Indian Ocean basins. This is clearly visible from the areas of upward and downward transport in the Weddell Sea (Figure 10b, d and f): The deep convection caused by the large additional salinity anomaly was balanced by upward motion just northward of the high-salinity region. 
Finally, we can speculate that the slighty $(\sim 10 \%)$ more intense Benguela Current in Experiment GC (Figures 8a, d and 9) could lead to a northward shift of the Angola-Benguela Frontal Zone by a few degrees and a reduced import of nutrients into the northern Benguela System (Berger and Wefer 2002). With regard to silicate, in the South Atlantic subtropical gyre today there is a maximum that can be identified with Upper Circumpolar Water, which lies below AAIW because of its much higher density. This water is enriched in silicate over AAIW because AAIW originates from silicate-poor surface waters, and over NADW because of the admixture of high-silicate Pacific and Antarctic waters (cf. Talley 1996 and references therein). North of $20^{\circ} \mathrm{S}$, the density of the silicate maximum is only slightly higher than that of the salinity minimum, because it is truncated from below by NADW. Again we can speculate that today, in a situation that resembles our Experiment $\mathrm{M}$, this water is partly mixed into SACW, possibly in upwelling cells such as those visible in Figure 10c, e and g just east of Cape Horn and within Drake Passage, and is advected with the Benguela, South Equatorial and Angola Currents to become a source for the silicate that is consumed in the Namibian upwelling region. In a situation akin to Experiment GC, the silicate maximum might be truncated from above by the upwelling of NADW in the Southern Ocean, and its silicate might be lost to the circulation with the South Atlantic subtropical gyre. Hence a circulation scheme as depicted in Figure 15b could possibly contribute to the resolution of the Walvis Opal Paradox: the fact that during glacial times of increased upwelling and organic matter supply to the sea floor, the flux of diatoms and other siliceous plankton remains was decreased (Berger and Wefer 2002). It would further resemble the pattern proposed by Michel et al 1995 to explain the glacial $\delta^{13} \mathrm{C}$ distribution, in which Subantarctic Mode water filled the deep ocean basins at the LGM.

\section{Oxygen-18}

Our model carried $\delta^{18} \mathrm{O}_{\mathrm{w}}$ as an additional passive tracer. This tracer was restored to the sparse and scattered modern annual-mean observations by
Schmidt et al. (1999). Thus there were no surface fluxes over the vast areas of the ocean that were void of data. As far as the surface ocean is concerned, the model acted like an interpolation or extrapolation method using advective and diffusive fluxes (Takahashi et al. 1997). The $\delta^{18} \mathrm{O}_{\mathrm{w}}$ tracer became even more artificial in the glacial experiments, but still served the purpose to highlight the effects of changes in advection and diffusion.

In spite of these limitations, the $\delta^{18} \mathrm{O}_{\mathrm{w}}$ distribution in Experiment $M$ compared well to the GEOSECS data (Birchfield 1987). The changes in the $\delta^{18} \mathrm{O}_{w}$ distribution exhibited by the glacial experiments were clearly related to changes in the meridional overturning circulation. For example, NADW was isotopically enriched because at the LGM the bulk of it was formed further to the south (cf. Figures 11 and 16). Similarly, the drastic changes of the $\delta^{18} \mathrm{O}_{w}$ of AABW reflected the changes in the location and intensity of convection in the Weddell Sea. Experiments GA and GB were characterized by only weak convection in the southern Weddell Sea, such that the bottom water $\delta^{18} \mathrm{O}_{\mathrm{w}}$ values were dominated by mixing with heavier water that originated from the North Atlantic Ocean. In Experiment GC, the high Weddell Sea SSS anomaly caused intense convection leading to AABW $\delta^{18} \mathrm{O}_{\mathrm{w}}$ values below zero, comparable to those of Experiment M. Besides the influence of NADW, these different bottom water $\delta^{18} \mathrm{O}_{w}$ ratios were linked to a latitudinal shift of the AABW formation region between the glacial experiments. Neither the location nor the rate of AAIW formation changed much, and therefore the $\delta^{18} \mathrm{O}_{\mathrm{w}}$ of AAIW was about $0.1-0.2 \%$ in all experiments.

Changes in the $\delta^{18} \mathrm{O}_{c}$ distribution were caused to a large extent by temperature changes. Below 2000 m, Experiments GA to GC reflected the increasingly colder deep and bottom waters. The difference in AABW $\delta^{18} \mathrm{O}_{\mathrm{c}}$ between Experiment GC and $\mathrm{M}$ amounted to $0.5 \%$, consistent with a cooling of about $1.0^{\circ} \mathrm{C}$ (not shown). The differences between Experiments $\mathrm{GC}$ and $\mathrm{M}$ were roughly consistent with reconstructed glacial-Holocene anomalies in benthic foraminiferal $\delta^{18} \mathrm{O}$ and a global ice-volume effect of about 1.2\%o (Matsumoto and Lynch-Stieglitz 1999). In agreement with 
Matsumoto and Lynch-Stieglitz (2001), they did not show an appreciable shift of the polar front in the Southern Ocean.

\section{Comparison to CLIMAP}

Based on the GLAMAP reconstruction, our model experiments resulted in a global mean SST anomaly of about $1.4^{\circ} \mathrm{C}$. According to the CLIMAP reconstruction, the present-day global mean SST is about $1.6^{\circ} \mathrm{C}$ higher than at the LGM. The smaller difference implied by GLAMAP is due to less sea-ice cover and distinctly higher SST in the high latitudes of the North Atlantic Ocean. In the low and mid latitudes, GLAMAP is colder than CLIMAP (see Figure 5 and the related discussion in Schäfer-Neth and Paul this volume). In conjunction with the available $\delta^{18} \mathrm{O}_{\mathrm{c}}$ measurements, the higher SST yielded a higher SSS and sea-surface density over most of the subpolar and polar North Atlantic Ocean, where it may cause deep convection and the formation of a relatively dense NADW. This was indeed the case in all our glacial model experiments.

\section{Other Model Simulations}

Combing global and regional modeling, we describe in a previous study (Schäfer-Neth and Paul 2001) experiments based on the temperature reconstruction by Weinelt et al. (1996), with similarly seasonally ice-free Nordic Seas and a sea-surface density field comparable to our present study. With the help of a global carbon-cycle box model, Schulz and Paul (2003) study the effect of these GLAMAPlike sea-surface conditions on the high-latitude $\delta^{13} \mathrm{C}$ distribution (Experiment "LGMW"in Schulz and Paul 2003; see also Matthies et al. this volume for a coupling to the Hamburg Ocean Carbon Cycle Model). Compared to $\delta^{13} \mathrm{C}$ reconstructions for the eastern North Atlantic Ocean, they find a better correspondance than in a case with CLIMAP ice cover (Experiment "LGMC"), because the water on the southern flank of the Greenland-IcelandScotland ridge is still ventilated from the north, although at a smaller rate. In our experiments, roughly half of the NADW was formed at convection sites south of $48^{\circ} \mathrm{N}$ where the overturning reached only $1500 \mathrm{~m}$ depth (Figure 11) and the convection was limited to $1000-1200 \mathrm{~m}$ depth (Figure 3); the rest still sank at or even north of the ridge.

There is a large number of other model simulations of the LGM ocean based on a wide variety of OGCMs, which for example employ air temperature and freshwater flux from an atmospheric model (Lautenschlager and Herterich 1990; Bigg et al. 1998), reconstructions of SST and SSS (Seidov et al. 1996; Winguth et al. 1999) or an energy balance model for the temperature boundary condition (Fieg and Gerdes 2001). Two coupled model studies were carried out with intermediate complexity models (Ganopolski et al. 1998; Weaver et al. 1998). Hewitt et al. (2001) were the first to present a multicentury simulation of the LGM with a three-dimensional atmosphere-ocean general circulation model. Further coupled model experiments were performed by Kitoh et al. (2001) and Shin et al. (2003). Some of these model studies obtain a meridional overturning circulation weaker, others stronger than today. This is consistent with our finding that, given the high sea-surface density in the northern North Atlantic Ocean as implied by the GLAMAP SST, the meridional overturning circulation could have been similar to today. In contrast to the present study, none of these other model simulations have so far focussed on the upper ocean hydrology and circulation.

In Experiments GA-GC, the subpolar sea-surface density gradient (Figure 4) occured over a smaller and more southern range of latitudes than in Experiment $\mathrm{M}$, which reflected the southward shift as well as the more zonal path of the glacial Gulf Stream and North Atlantic Drift. It is this pattern and the still active although reduced exchange of water masses between the northeastern Atlantic Ocean and the Nordic Seas that compares particularly well with the LGM results of the coupled model by Hewitt et al. (2001). They also find that there is still some weak convection in the Norwegian Sea, and in the midlatitudes even more heat than at present is transported by the strong subpolar gyre circulation.

In a different coupled model, the NCAR CCSM by Shin et al. (2003), the tropics show a glacial cooling of $3^{\circ} \mathrm{C}$ over land and $2^{\circ} \mathrm{C}$ over the ocean. Thus the SST is about $1^{\circ} \mathrm{C}$ lower than in the 
CLIMAP reconstruction, which also applies to GLAMAP (see again Figure 5 in Schäfer-Neth and Paul this volume). With respect to the SSS in the Weddell Sea, they find a large anomaly of about 1.5 , excluding the global salinity increase of 1 . As we anticipated in our series of model experiments GA-GC, this salinity anomaly under sea ice is mainly due to the release of brine during winter seaice formation and the subsequent sea-ice export to lower latitudes. Its magnitude is even larger than in our most extreme case (Experiment GC with a Weddell Sea SSS anomaly of 1.0).

\section{Conclusions}

With its high vertical resolution, low vertical diffusivity and isopycnal mixing, our ocean model realistically simulated the circulation of the thermocline and intermediate waters as well as the characteristics of the deep ocean. In particular, the vertical diffusion of only $0.1 \mathrm{~cm}^{2} \mathrm{~s}^{-1}$ in the upper $2000 \mathrm{~m}$ allowed for very low rates of upwelling from the deep ocean into the tropical thermocline and thus a more intact conveyor belt. Together with the isopycnal mixing parameterization, we achieved a better representation of the subsurface flow field than in our previous modeling studies (Paul et al. 1999; Schäfer-Neth and Paul 2001).

In our ocean model, the ventilated thermocline was cooler during the LGM than today by $2-3^{\circ} \mathrm{C}$ in the North and $4-5^{\circ} \mathrm{C}$ in the South Atlantic Ocean. In the tropics, its depth was reduced by up to 150 $m$. In the North Atlantic Ocean, the outcrop locations of the thermocline isopycnal surfaces migrated southward by $5^{\circ}-10^{\circ}$, and the ventilation increased. In the South Atlantic Ocean, the ventilated thermocline shoaled to the southwest of Cape of Good Hope. Correspondingly, the mixed-layer and thermocline water masses were dominated by cold water that originated from near Drake Passage as opposed to warm water from the Indian Ocean. In the equatorial region $\left(5^{\circ} \mathrm{S}-5^{\circ} \mathrm{N}\right)$, the east-west slope of the depth of the mixed layer and the permanent thermocline increased, which was accompanied by a general cooling of about $2^{\circ} \mathrm{C}$.

Given the high density implied by the GLAMAP SST reconstruction for the surface of the northern North Atlantic Ocean, the modeled formation and export of NADW across the equator was nearly unchanged. The flow of AABW depended strongly on the SSS in the Weddell Sea. In the glacial experiment with the largest Weddell Sea salinity anomaly, it was of similar strength as in the modern experiment, but reached further north. The size of the Weddell Sea salinity anomaly also influenced the strength of the ACC. A stronger ACC flow led to a more intense Agulhas retroflection and a leakage of warm Indian Ocean water westward into the South Atlantic Ocean that was reduced by up to $60 \%$ with respect to its modern value. Hence the cold water route became the primary path for NADW renewal.

Based on the comparison of our modern and LGM experiments, we speculate that a slighty more intense Benguela Current might lead to a northward shift of the Angola-Benguela Frontal Zone and, in conjunction with enhanced upwelling of NADW in the Southern Ocean, to a reduced import of silicate into the Benguela System, which could partially resolve the Walvis Opal Paradox (Berger and Wefer 2002).

In the LGM experiment with the largest Weddell Sea SSS anomaly, the AABW $\delta^{18} \mathrm{O}_{w}$ values were comparable to those of the modern experiment. Although $\delta^{18} \mathrm{O}_{w}$ was restored to the same surface values and only reflected changes in advection and diffusion, the resulting $\delta^{18} \mathrm{O}_{\mathrm{c}}$ distribution came close to reconstructions based on fossil shells of benthic foraminifera.

\section{Acknowledgments}

We thank Guy Delaygue and an anonymous referee for their constructive comments that helped to improve our manuscript considerably. This research was funded by the Deutsche Forschungsgemeinschaft (DFG) as part of the Sonderforschungsbereich 261, No. 374, and DFG Research Center Ocean Margins of the University of Bremen, No. RCOM 0083.

\section{References}

Berger WH, Wefer G (1996) Expeditions into the past: Paleoceanographic studies in the South Atlantic. In: Wefer G, Berger WH, Siedler G, Webb DJ (eds) The South Atlantic: Present and Past Circulation. 
Springer, Berlin, pp 363-410

Berger WH, Wefer G (2002) On the reconstruction of upwelling: Namibian upwelling in context. Mar Geol 180:3-28

Biastoch A, Krauss W (1999) The role of mesoscale eddies in the source regions of the Agulhas Current. J Phys Oceanogr 29: 2303-2317

Bigg GR, Wadley MR, Stevens DP, Johnson JA (1998) Simulations of two last glacial maximum ocean states. Paleoceanography 13: 340-351

Bigg GR, Rohling EJ (2000) An oxygen isotope data set for marine water. J Geophys Res 105: 8527-8535

Birchfield GE (1987) Changes in deep-ocean water $\delta^{18} \mathrm{O}$ and temperature from the last glacial maximum to the present. Paleoceanography 2: 431-442

Borowski D, Gerdes R, Olbers D (2002) Thermohaline and wind forcing of a circumpolar channel with blocked geostrophic contours. J Phys Oceanogr 32: 25202540

Boyle EA (2000) Is the ocean thermohaline circulation linked to abrupt stadial/interstadial transitions? Quat Sci Rev 19: 255-272

Bryan K, Lewis LJ(1979) A water mass model of the world ocean circulation. J Geophys Res 84: 2503-2517

Clarke PU, Mix AC (2002) Ice sheets and sea level of the Last Glacial Maximum. Quat Sci Rev 21: 1-7

CLIMAP Project Members (1981) Seasonal reconstructions of the Earth's surface at the Last Glacial Maximum. Geological Society of America, Map and Chart Series MC-36, $18 \mathrm{p}$

De Ruijter WPM, Biastoch A, Drijfhout SS, Lutjeharms JRE, Matano RP, Pichevin T, van Leeuwen PJ, Weijer W (1999) Indian-Atlantic interocean exchange: Dynamics, estimation and impact. J Geophys Res C 104: 20,885-20,910

Duncan CP, Schladow SG, Williams WG (1982) Surface currents near the Greater and Lesser Antilles. Int Hydrogr Rev 59: 67-78

Duplessy JC, Labeyrie L, Juillet-Leclerc A, Maitre F, Duprat J, Sarnthein M (1991) Surface salinity reconstruction of the North Atlantic Ocean during the last glacial maximum. Oceanol Acta 14: 311-324

Duplessy J-C, Labeyrie L, Paterne M, Hovine S, Fichefet T, Duprat J, Labracherie M (1996) High latitude deep water sources during the Last Glacial Maximum and the intensity of the global oceanic circulation. In: Wefer G, Berger WH, Siedler G, Webb DJ (eds) The South Atlantic: Present and Past Circulation. Springer, Berlin, pp 445-460

England MH, Garçon V (1994) South Atlantic circulation in a world ocean model. Ann Geophys 12: 812-825

Epstein S, Buchsbaum R, Lowenstam HA, Urey HC
(1953) Revised carbonate-water isotopic temperature scale. Geol Soc Am Bull 64: 1315-1325

Fieg K, Gerdes R (2001) Sensitivity of the thermohaline circulation to modern and glacial surface boundary conditions. J Geophys Res 106: 6853-6867

Ganopolski A, Rahmstorf S, Petoukhov V, Claussen M (1998) Simulation of modern and glacial climates with a coupled model of intermediate complexity. Nature 391:351-356

Gent PR, McWilliams JC (1990) Isopycnal mixing in ocean circulation models. J Phys Oceanogr 20: 150155

Gordon A (1986) Interocean exchange of thermohaline water. J Geophys Res 91: 5037-5046

Hall MM, Bryden HL (1982) Direct estimates and mechanisms of ocean heat transport. Deep-Sea Res 29: 339359

Harms S, Fahrbach E, Strass VH (2001) Sea ice transports in the Weddell Sea. J Geophys Res C 106: 9057-9073

Hewitt CD, Broccoli AJ, Mitchell JFB, Stouffer RJ (2001) A coupled model study of the last glacial maximum: Was part of the North Atlantic relatively warm? Geophys Res Lett 28: 1571-1574

Huang RX, Qiu B (1994) Three-dimensional structure of the wind-driven circulation in the subtropical North Pacific. J Phys Oceanogr 24: 1608-1622

Kalnay E et al. (1996) The NCEP/NCAR reanalysis project. Bull Am Met Soc 77: 437-471

Kitoh A, Murakami S, Koide H (2001) A simulation of the Last Glacial Maximum with a coupled oceanatmosphere GCM. Geohys Res Lett 28:2221-2224

Klein B, Molinari R, Siedler G, Müller TJ (1995) A transatlantic section at $14.5^{\circ} \mathrm{N}$ : Meridional volume and heat fluxes. J Mar Res 53: 929-957

Krauss W (1986) The North Atlantic Current. J Geophys Res 89:3407-3415

Lautenschlager M, Herterich K (1990) Atmospheric response to ice age conditions: Climatology near the Earth's surface. J Geophys Res D 95: 22,547-22,557

Large WG, Danabasoglu G, Doney SC, McWilliams JC (1997) Sensitivity to surface forcing and boundary layer mixing in a global ocean model: Annual-mean climatology. J Phys Oceanogr 27: 2418-2447

Ledwell JR, Watson AJ, Law CS (1993) Evidence for slow mixing across the pycnocline from an open-ocean tracer release experiment. Nature 364: 701-703

Levitus S (1982) Climatological atlas of the World Ocean. NOAA Prof. Paper No. 13, 173 p

Matsumoto K, Lynch-Stieglitz J (1999) Similar glacial and Holocene deep water circulation inferred from southeast pacific benthic foraminiferal carbon isotope composition. Paleoceanography 14: 149-163 
Matsumoto K, Lynch-Stieglitz J (2001) Similar glacial and Holocene Southern Ocean hydrography. Paleoceanography 16 : 445-454

Melles M (1991) Late Quaternary paleoglaciology and paleoceanography at the continental margin of the southern Weddell Sea, Antarctica. Ber Polarforsch, Bremerhaven, Germany, 81, 190 p

Michel E, Labeyrie LD, Duplessy JC, Gorfti N, Labracherie M, Turon JL (1995) Could deep Subantarctic convection feed the world deep basins during the last glacial maximum? Paleoceanography 10:927-942

Mix AC, Bard E, Schneider R (2001) Environmental processes of the ice age: Land, oceans, glaciers (EPILOG) Quat Sci Rev 20: 627-658

NCAR Data Support Section (1986). NGDC ETOPO5 global ocean depth \& land elevation, 5-min. Data Set 759.1, National Center for Atmospheric Research, Boulder, Colorado

Pacanowski RCE (1996) MOM 2. Documentation, User's Guide and Reference Manual. Technical Report 3.2, GFDL Ocean Group, GFDL, Princeton, New Jersey

Peterson RG, Stramma L (1991) Upper-level circulation in the South Atlantic Ocean. Prog Oceanogr 26: 1-73

Paul A, Mulitza S, Pätzold J, WolffT (1999) Simulation of oxygen isotopes in a global ocean model. In: Fischer G, Wefer G (eds) Use of Proxies in Paleoceanography: Examples from the South Atlantic. Springer, Berlin, pp 655-686

Paul A, Schäfer-Neth C (2003) Modeling the water masses of the Atlantic Ocean at the Last Glacial Maximum. Paleoceanography 18: doi: 10.1029/ 2002PA000783

Peltier WR (1994). Ice age paleotopography. Science 265 : 195-201

Pether J (1994) Molluscan evidence for enhanced deglacial advection of Agulhas water in the Benguela Current off southwestern Africa. Palaeogeogr Palaeoclimatol Palaeoecol 111: 99-117

PMIP (1993) Paleoclimate modelling intercomparison project, http://www-pcmdi.llnl.gov/pmip/newsletters/newsletter02.html.

Rintoul SR (1991) South Atlantic interbasin exchange. J Geophys Res 96: 2675-2692

Sarnthein M, Gersonde R, Niebler S, Pflaumann U, Spielhagen R, Thiede J, Wefer G, Weinelt M (2003) Preface: Glacial atlantic ocean mapping (GLAMAP2000). Paleoceanography 18: doi: 10.1029/2002PA 00769

Schäfer-Neth C (1998) Changes in the seawater-oxygen isotope relation between last glacial and present:
Sediment core data and OGCM modelling. Paleoclimates 2: 101-131

Schäfer-Neth C, Paul A (2001) Circulation of the glacial Atlantic: A synthesis of global and regional modeling. In: Schäfer P, Ritzrau W, Schlüter M, Thiede J (eds) The northern North Atlantic: A changing environment. Springer, Berlin, pp 441-462

Schmid C, Siedler G, Zenk W (2000) Dynamics of intermediate water circulation in the subtropical South Atlantic. J Phys Oceanogr 30: 3191-3211

Schmidt GA, Bigg GR, Rohling EJ (1999) Global seawater oxygen-18 database. http://www.giss.nasa.gov/ data/o18data, Goddard Institute for Space Studies, New York

Schulz M, Paul A (2003) Sensitivity of the ocean-atmosphere carbon cycle to ice-covered and ice-free conditions in the Nordic Seas during the Last Glacial Maximum. Palaeogeogr Palaeoclimatol Palaeoecol, in press

Seidov D, Sarnthein M, Stattegger K, Prien R, Weinelt M (1996) North Atlantic ocean circulation during the Last Glacial Maximum and a subsequent meltwater event: A numerical model. J Geophys Res C 101: $16,305-16,332$

Shannon LV, Nelson G (1996) The Benguela: Large scale features and processes and system variability. In: Wefer G, Berger WH, Siedler G, Webb DJ (eds) The South Atlantic: Present and Past Circulation. Springer, Berlin, pp 163-210

Shin S-I, Liu Z, Otto-Bliesner B, Brady EC, Kutzbach JE, Harrison SP (2003) A simulation of the Last Glacial Maximum climate using the NCAR-CCSM. Clim Dyn 20: $127-151$

Slowey NC, Curry WB (1995) Glacial-interglacial differences in circulation and carbon cycling within the upper western North Atlantic. Paleoceanography 10: 715-732

Sloyan BM, Rintoul SR (2001) The Southern Ocean limb of the global deep overturning circulation. J Phys Oceanogr 31: 143-173

Sprintall J, Tomczak M (1992) Evidence of the barrier layer in the surface layer of the Tropics. J Geophys Res C 97: 7305-7316

Takahashi T, Feely RA, Weiss RF, Wanninkhof RH, Chipman DW, Sutherland SC, Takahashi TT (1997) Global air-sea flux of $\mathrm{CO}_{2}$ : An estimate based on measurements of sea-air $\mathrm{pCO}_{2}$ difference. Proceedings of the National Academy of Sciences 94: 82928299

Thompson SR, Stevens DP, Döös K (1997) The importance of interocean exchange south of Africa in a numerical model. J Geophys Res 102: 3303-3315 
Timmermann R, Beckmann A, Hellmer HH (2001). The role of sea ice in the fresh water budget of the Weddell Sea. Ann Glaciol 33: 419-424

Toggweiler JR, Samuels B (1995a) Effect of Drake Passage on the global thermohaline circulation. DeepSea Res 42: 477-500

Toggweiler JR, Samuels B (1995b). Effect of sea ice on the salinity of Antarctic bottom waters. J Phys Oceanogr 25: 1980-1997

Tomczak M, Godfrey JS (1994) Regional Oceanography: An Introduction. Pergamon, Oxford, England

Tsuchiya M (1989) Circulation of the Antarctic Intermediate Water in the North Atlantic Ocean. J Mar Res 47:747-755

Tsuchiya M, Talley LD, McCartney MS (1994) A western Atlantic section from South Georgia Island $\left(54^{\circ} \mathrm{S}\right)$ northward across the equator. J Mar Res 52: 55-81

Weaver AJ, Eby M, Fanning AF, Wiebe EC (1998) The climate of the last glacial maximum in a coupled atmosphere-ocean model. Nature 394: 847-853

Weinelt M, Sarnthein M, Pflaumann U, Schulz H, Jung S, Erlenkeuser H (1996) Ice-free Nordic Seas during the Last Glacial Maximum? Potential sites of deep- water formation. Paleoclimates 1:283-309

Whitworth III. T, Peterson RG (1985) Volume transport of the Antarctic Circumpolar Current from bottom pressure measurements. J Phys Oceanogr 15: 810816

Williams RG, Spall MA, Marshall JC (1995) Does Stommel's mixed layer "demon" work? J Phys Oceanogr 25: 3089-3102

Winguth AME, Archer D, Duplessy JC, Maier-Reimer E, Mikolajewicz, U (1999) Sensitivity of paleonutrient tracer distributions and deep-sea circulation to glacial boundary conditions. Paleoceanography 14: 304-323

Winter A, Martin K (1990) Late Quarternary history of the Agulhas Current. Paleoceanography 5: 479-486

WOA (1998) World ocean atlas 1998, http:// www.nodc.noaa.gov/oc5/woa98.html. National Oceanographic Data Center, Silver Spring, Maryland

Wolff T, Mulitza S, Rühlemann C, Wefer G (1999) Response of the tropical Atlantic thermocline to late Quaternary trade wind changes. Paleoceanography 14:374-383 